\title{
Can Plants' Ability for DNA Repair and Stress Defense be Used against Patients' Circulating Tumor Cells?
}

\author{
C.D. Volko and U.D. Rohr
}

Endobal Medical Research Company, 1103 E. Tropicana Ave. \#3006, Las Vegas, Nevada 89119, USA

\begin{abstract}
Introduction: It was suggested that specific plants may reduce cancer's resistance to chemotherapy. Resistance inhibits apoptosis, as well as other fundamental anti-cancer protective mechanisms. Soy bean has been found to reduce cellular stress and repair DNA damage caused by drought or parasites, and can transfer this defense mechanism to other plant species as well. The aim of this study is therefore to conduct a systematic comparison of the effect of soy bean formulation (FSWW08) on gene expression in in vitro human breast cancer cell line, and in in vivo in blood circulating tumor cells (CTC), after oral consumption of FSWW08 by patients suffering from breast-, ovarian-, and prostate cancer.

Method: In vitro gene expressions studies were conducted with the human breast cancer cell line BT-474 that was exposed to doxorubicin or FSWW08, either alone or in combination. Ovarian-, prostate-, and breast cancer patients received FSWW08 for 30 days. CTC were extracted from their blood according to an established protocol. Gene expression evaluations were conducted before and after treatment.

Results: In vitro, the multi-drug resistance (MDR) protein was reduced by FSWW08, but was increased by doxorubicin. The combination of FSWW08 and doxorubicin, however, showed a protective effect against the increase of MDR in physiologic concentrations, increased, however, also in high experimental concentrations of both agents. The expression of several cancer-related protective genes, such as tumor suppressor factors p21, p38 and p53, was improved by FSWW08 in vitro and in vivo, which helped cell differentiation and new tissue formation. Additionally, the $\mathrm{BAX} / \mathrm{Bcl}_{2}$ ratio was improved, in vitro, as well as gene expression of estrogen receptor beta, NF-kB, MAP kinase, c-JUN, and matrix metalloproteinase 9, together with an increase of VEGF expression in vivo in CTC.

Conclusion: It was demonstrated that FSWW08 improved the gene functions related to DNA repair and stress in human blood CTC and resistance marker, in vitro, when applied in combination with doxorubicin. As such, larger in vitro and in vivo clinical studies that investigate single botanical compounds from other plants, are warranted.
\end{abstract}

Keywords: Tp53, Tp21, Bax/Bcl2, MAP kinase, VEGF, CTC, circulating tumor cell, fermented soy, MDR protein, estrogen receptor beta, NF-KB, RT-PCR technique, human breast cancer cell line BT-474, ovarian cancer, breast cancer, prostate cancer.

\section{INTRODUCTION}

During World War II, the US government developed protective measures against cancer [1]. This served as the model for a long series of similar agents (alkylating agents) killing rapidly growing cancer cells by damaging their DNA - the beginning of chemotherapy [1].

According to experts in the field two problems have to be solved to improve chemotherapy: Resistance and side effects [2-6]. Several new approaches are now being studied, including new drugs, new combinations of drugs, new delivery techniques, novel approaches that target drugs more specifically at the cancer cells, first, drugs to reduce side effects and second, agents that overcome multi-drug resistance [2-6]. Several reviewers suggested that plant based formulations may inhibit resistance against cancer therapy, including Isoflavones, curcuma, vitamin A, and some extracted ingredients from Chinese herbs [4].

*Address correspondence to this author at the $1101 \mathrm{E}$. Tropicana Ave. \#3006, Las Vegas, Nevada 89119, USA; Tel: 12023216621 ;

E-mail: uwerohr@gmail.com
A new concept suggests that cancer develops from a small group of cells similar to stem cells, which means that they are not fully differentiated, show impaired hormone receptor expression (Figure 1) and are both the origin of cancer (Figure 2) and responsible for metastasis through migration (Figure 3) [6]. The cancer stem cell theory has profound implications for cancer chemotherapy because it explains why it is effective in more differentiated cells but ineffective in cancer stem cells [6]. The spread of cancer is facilitated via migration of the blood (circulating tumor cells or CTC) or the lymph system to other organs (Figure 3). It was suggested that plant based natural agents may be particularly effective managing CTC, which was shown in vitro [7]. Several chemotherapeutic agents, which do stop fast growing tumors, have the opposite effect on cancer stem cells, causing them to divide too rapidly [8], as well as increasing stress related oxygen species (ROS), causing resistance to the therapy, whereas some plant ingredients are able to reduce ROS and reduce stress resistance to cancer therapy [9].

Scientists explain human cancers which sustained proliferation, escape from apoptosis, and genomic (C) 2015 Lifescience Global 
instability by mutations of the TP53, ATM (ataxiatelangiectasia mutated (ATM) gene, and MDM2 (Mouse double minute 2 homolog) genes [10]. It is defined that DNA replication stress generates genomic instability and causes suppressed apoptosis [10-21].

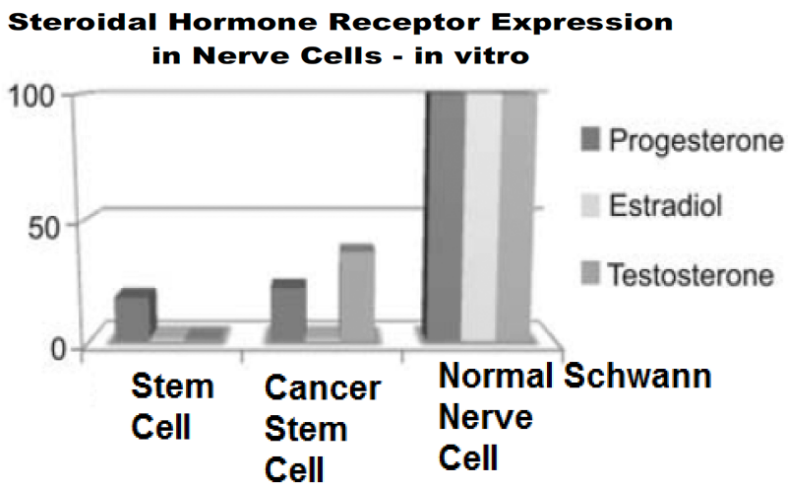

Figure 1: Hormone receptor distribution in stem cells, cancer stem cells, and normal fully differentiated Schwann cells, taken from [28].

Recently, researchers have suggested that dietary compounds such as curcumin, sulforaphana, soy Isoflavones, epigallocatechin-3-gallate, resveratrol, lycopene, piperine and vitamin D3 can directly or indirectly affect cancer stem cell self-renewal pathways [9], as well as reduce unfavorable cellular stress caused by chemotherapy and making chemotherapy more effective $[23,24]$. Plants have evolved to live in environments where they are often exposed to different stress factors in combination and are subject to high levels of DNA damage resulting from the plant's obligatory dependence on environmental stresses like solar UV radiation, attacks of yeasts to digest plants, drought, chilling injury, and other air and soil pollutants including heavy metals and metabolic by-products from endogenous processes [24]. Therefore, to survive under frequent and extreme environmental stress conditions, plant cells have evolved with highly efficient and wide-ranging mechanisms for the detection and repair of DNA damage to eliminate the chances of permanent genetic alterations and to maintain genome stability for faithful transfer of genetic information over generations [26-28].

Classically plant based anticancer medicine is toxic, often inhibits mitosis, follows the first generation anticancer drugs made from mustard gas and has severe side effects. The here outlined mechanism of DNA repair differs completely from this strategy: it is a non-toxic mechanism, since plants under environmental stress attack are already severely immunologically compromised and need no further reduction of defense mechanisms [25] The DNA repair under stress is a mechanism to strengthen impaired plants. Yeasts and plants share genes for cell repair and DNA protection with mammals like MAPkinase and heat shock protein (Figure 4) [25]. MAPkinase cascades are crucial in eukaryotes for transducing the perception of environmental stimuli into internal signaling pathways [30]. Plants have a particularly

\section{Cancer Stem Cell Model}

\section{Invasive carcinoma Cancer stem cell survive Recurrence}

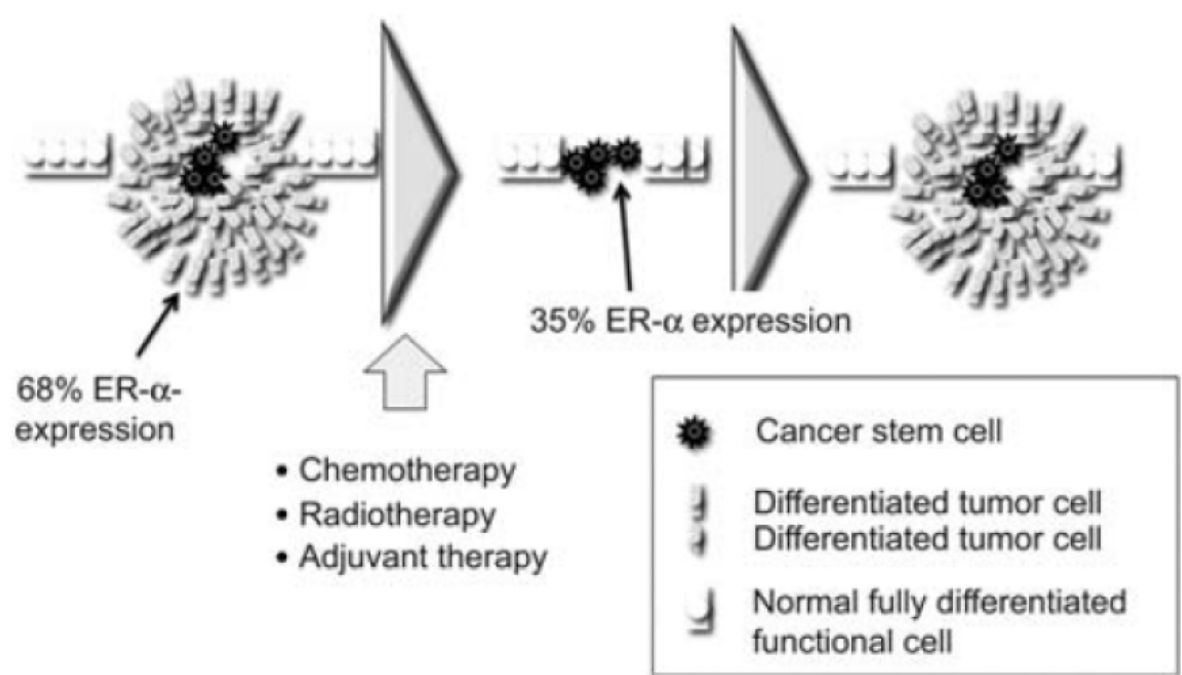

Figure 2: Schematic depiction of invasive breast cancer. Primary breast cancer consists of two types of cancer cells. Cancer stem cells have only low estrogen receptor expression, whereas primary cancer consists of cancer cells expressing $62 \%$ estrogen receptor. Chemo-, radio-, or adjuvant therapy cannot reduce cancer stem cells, because they have virtually no estrogen receptor expression. Therefore, cancer recurrence is difficult to predict. (See ref [28]). 


\section{Circulating Tumor Cells (CTC) Spread from Primary Tumor}

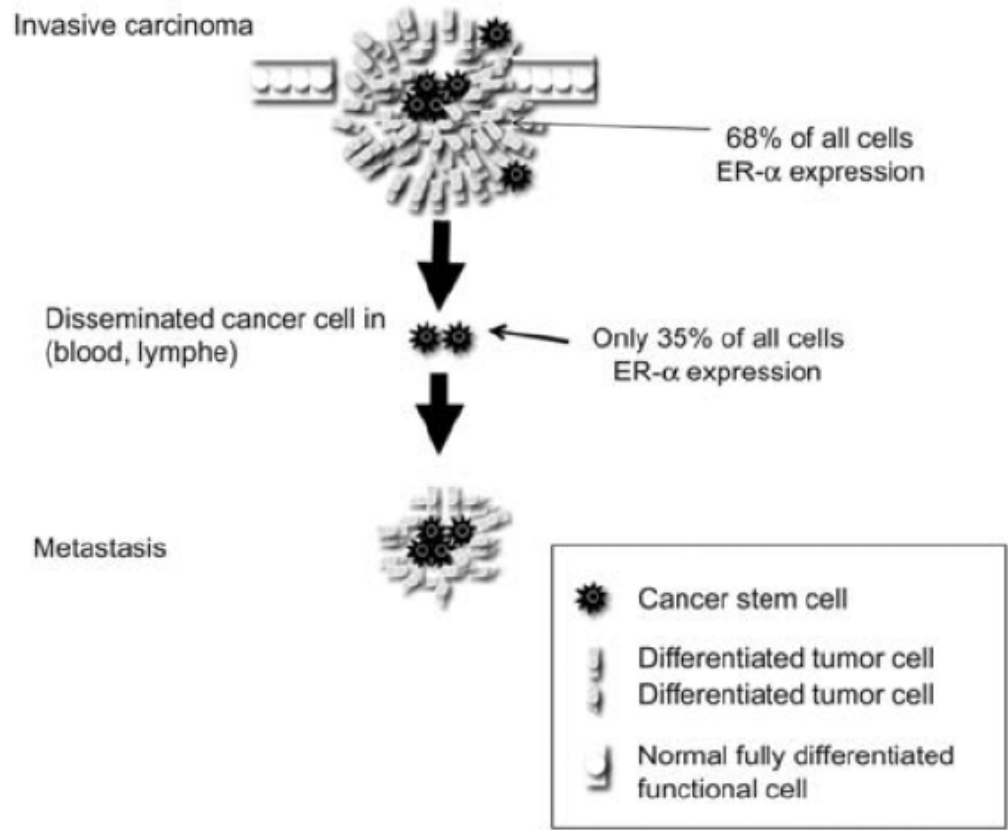

Figure 3: Tumor spread is facilitated via cancer stem cells, which have very low estrogen receptor expression and might not respond to chemo-, radio-, or adjuvant therapy.

large number of MAPkinase components, allowing for the control over a wide range of stress response pathways [31]. Interestingly, in Arabidopsis, a unique plant-specific transcription factor Suppressor of Gamma Response 1 (SOG1) acts as the main regulator in DNA damage repair and performs analogous functions to mammalian tp53, which is involved in a majority of the plant's response to DNA damage, such as transcriptional response, activation of cell cycle checkpoint and programmed death of stem cells [32]. It is a tremendously important finding that in plants a factor similar to tumor suppressor factor tp53 exists, which is a hallmark gene factor for cell differentiation in mammals, since in more than $50 \%$ of all tumors tp53 is missing [33]. Transcription analyses in Arabidopsis plants and many others have revealed that a fairly high proportion of the genes are associated with DNA damage repair [34, 35].

Transcription factors are controlled by plant hormones and small proteins (Figure 4): The expression of soybean miRNAs was investigated in response to water deficit and infection with soybean rust fungus, where all miRNAs were differentially regulated by each stress, usually in an opposite direction [36]. It has been shown that soybeans are able to affect stress response in other species too, like tomato plants as well as tobacco plants [37]. There are numerous studies showing that soy can alter the genome in human cancer cells [38]. This paper therefore systematically investigates the effect of fermented soy bean formulation on cancer cells in vitro,

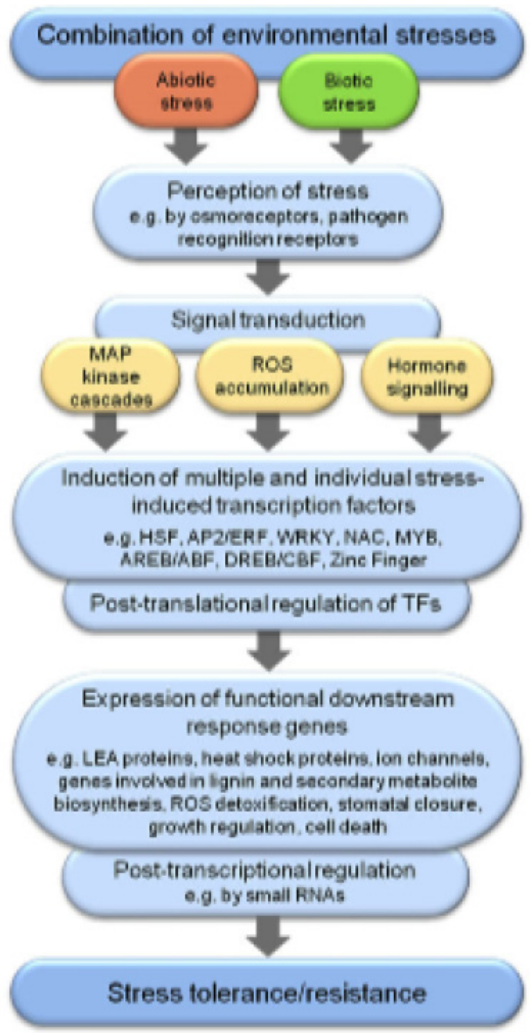

Figure 4: Key events in the signal transduction pathway activated in response to combined biotic and abiotic stresses (taken from ref. [17]). 
as was shown by others also, in vivo in CTC extracted from blood from cancer patients, which has not been shown before. We detected and reported earlier that the effectiveness of chemotherapy was increased by fermented soy formulation, side effects were reduced, and survival increased $[39,40]$. This study investigates in vitro whether a combination of the classic cytotoxic compound doxorubicin may be combined with fermented soy bean and counterbalance some of the side effects of classical chemotherapy on the genetic level. For the first time ever stress DNA repair genes are investigated in blood circulating tumor cells (CTC) in vivo altered by a processed plant.

\section{MATERIALS AND METHODS}

\section{a. IRB}

The study protocol was reviewed by a local institutional review board (IRB) to protect the rights of patients, safety and well-being of humans involved in a clinical trial by reviewing all aspects of the trial and approving its startup and was published previously [24, $39,40]$. All patients had to sign an Informed Consent Form after the physician explained the study and he read the informed consent form where the study goal was outlined in a written form, in which the study was outlined and participation was voluntarily and it was explained individually to all patients that they could leave the study at any time even without explanation. No patient received a financial compensation for participating in the study, besides received the medication for free. The study fulfilled the Convention of Helsinki in its current form. The data were stored at the Hospital and the data were processed anonymous to protect the identity of the patient.

\section{b. In Vitro Gene Expression Investigation}

All in vitro procedures determining the gene expression determination have been described before [24, 39, 40, 44], however a more thorough investigation and discussion about in vitro and in vivo comparison and DNA repair is missing. Investigations of the human breast cancer cell line BT-474 were conducted, which were purchased from the German National Resource Centre for Biological Material (DSMZ, Leibniz Institute DSMZ-German Collection of Microorganisms and Cell Cultures, Inhoffenstraße 7B, 38124 Braunschweig, GERMANY, EU). It is a human breast tumor-cell line and was established from a solid invasive ductal carcinoma of the breast (DSMZ No.: 64 . WWW.DSMZ.de).
Doxorubicin hydrochloride was solved as $10 \mathrm{mg}$ in 5 $\mathrm{ml}$ volume aqueous solution and purchased from HEXAL AG, 83607 Holzkirchen, Germany, EU.

FSWW08 (Haelan 951, Organic NON-GMO Soy), a fermented Soy Bean Beverage made in China, is distributed by Haelan Products INC., 18568 142nd Ave. N.E. Bldg.F. Woodinville, WA 98072 U.S.A., www.haelan951.com. FSWW08 was given as a donation. FSWW08 contains $250 \mathrm{mg}$ soy Isoflavones per $235 \mathrm{ml}$.

\section{Culture Medium}

A RPMI Medium with FBS was employed according to the recommended condition of DSMZ Cell Culture Data. For every test $1 \times 105$ BT-474 tumor cells were used. Growth was induced on a 24 Well-plate (CELLSTAR) purchased by Greiner bio-one. After adding the drug substances, the cells were incubated over a period of $72 \mathrm{~h}$ at a temperature of $37^{\circ}$ Celsius in an incubator.

\section{Processing of Harvested Cells}

Cells were processed according to recommended procedures by Quiagen with a QIAmp RNA Blood Mini Kit to obtain total-RNA. This was obtained by cryopreservation and Freeze-Drying Protocols of the cell pellet with Quiagen RLT-buffer. Further isolation of RNA was performed by QIA shredder column and QIA spin column. The RNA containing elute was evaluated by reverse transcription. The reaction was conducted with the help of random hexamers and M-MLV transcriptase, so that RNA was transformed to cDNA.

\section{Gene-Expression Determination}

Quantitative Real-Time RT-PCR was employed to measure mRNA gene expression. Gene expression measurements were conducted with Sequence Detector 7700 by Applied Biosystems (ABI) Life Technologies, 3175 Staley Rd, Grand Island, NY 14072, USA. A 5'-Nuclease Assay was employed, which was developed by $A B I$. The method is based on measurement of quantitative determination of CDNA as an equivalent amount of mRNA. For quantitative purposes every gene expression determination was done with a control cell line, which contained mRNA as a standard. The dilution of the control cell line was done in ratio of 1:10.

The measurement was done in a relation as a fraction to an amount of cDNA $2 \times 106$. The value obtained in the Real-Time RT-PCR is the cell equivalent (CEQ). All measurements were done in triplicate. 
The measured gene expression determination was related to GAPDH and normalized to allow comparison among each other. As an additional method all obtained values were normalized to 1 as an untreated tumor, so that a relative gene expression is expressed in all figures.

\section{Dosing of Test Substances}

Doxorubicin is used in cancer mono therapy usually in a dose of $50-80 \mathrm{mg} / \mathrm{m}^{2}$ body surface. The average body surface of an adult is usually $2 \mathrm{~m}^{2}$. The injection solution is composed of $2 \mu \mathrm{g}$ Doxorubicin/ $\mu$ l. The amount of blood of an adult person is 5-7 Liter on the average. The dose of FSWW08 is one bottle containing $236 \mathrm{ml}$ per day, half a dose $118 \mathrm{ml}$ twice a day. Substances were tested alone and in combination and compared with an untreated cell line. Gene expression of parameters (BCL2, BAX, Topoll, MDR1, ERBB2 and others, Table 2) in different concentrations were measured. The questions to answer are:

a) What are the effects of Doxorubicin monotherapy on the expression of genes related to the mamma carcinoma cell line BT-474?

b) What are the effects of the combination of Doxorubicin and FSWW08 on the gene expression in the cell line BT-474?

c) Is it possible to obtain similar results when combining Doxorubicin with FSWW08 as in using Doxorubicin alone on BT-474?

d) In vivo gene expression of tumor cells circulating in blood extracted from patients

\section{Patients' Characteristics}

A pilot study was conducted with 5 ovarian cancer patients, 5 prostate cancer patients, and 7 breast cancer patients ( $\mathrm{pT} 1$ to $\mathrm{pT} 4$, pN0 to PN2, Mo).

\section{Blood Sampling}

Two samples of $5 \mathrm{ml}$ ethylenediamine tetraacetic acid blood were collected for isolation of CTCs before the application of therapeutic substances with an SMonovette ${ }^{\circledR}$ (Sarstedt AG \& Co, Nürmbrecht, Germany) and were stored at $4^{\circ} \mathrm{C}$ until further examination. The samples were processed immediately or not later than 4 hours after blood withdrawal. An additional serum sample was collected to determine serum tumor markers.

\section{Extracting Cancer Tumor Cells from Blood}

The methods are described in [40].

\section{Method of Determination of Gene Expression}

The method is described above as in vitro and was used with the same laboratory protocols and equipment. The lower detection limit of this assay is based on spiking experiments two cells per $5 \mathrm{ml}$ [41]. Examination of blood samples of healthy donors ( $n=$ 20) yielded a specificity of $95 \%$, which corroborates values in the literature [10]. We detected in all ovarian $(100 \%)$, all prostate cancer $(100 \%)$ as well as in 5 from 7 women suffering from breast cancer CTC (71\%), which is higher than reported in the literature [41].

\section{c. Gene Expression in CTC in Cancer Patients Extracted from Blood}

We relate gene expression results to two clinical trials, where we investigated a) in a pilot trial over a 4 year period survival [40] and well-being of prostate-, breast- and ovarian cancer, and b) in a multicenter placebo controlled trial in 268 patients [39]. We compared FSWW08 with a casein solution. Besides cachexia, white blood counts and other blood parameters were determined. Patient characteristics can be found in the literature $[39,40]$.

\section{Statistical Evaluation}

A t-test compares the means of two groups. For example, compare whether relative gene expression differs between a control and treated group. The t test compares one variable between two groups. The ttests (and related nonparametric tests) compare exactly two groups. Software was used of the 2014 version of GraphPad Software, Inc., 7825 Fay Avenue, Suite 230, La Jolla, CA 92037 USA,

\section{RESULTS}

The effects of Doxorubicin and FSWW08 on gene expression on GAPDH of BT-474 cells were investigated separately and compared to untreated BT474 cells (Table 1) (Figure 5). Both Doxorubicin and FSWW08 resulted in reduction of the cell morphology and gene expression of BT-474 (Table 1, Figure 5). Doxorubicin: The expression of GAPDH was decreased by $50 \%$ with low DOX concentration and by more than $90 \%$ at higher DOX concentrations. This implies a significant reduction of the number of surviving tumor cells (Table 1, Figure 5). FSWW08: FSWW08 resulted in a 5-fold decrease of GAPDH gene expression compared to untreated tumor cells and caused up to a 10 -fold decrease. This means that FSWW08 had a significant effect on the number of surviving tumor cells. Both Doxorubicin and FSWW08 have to be considered cytotoxic (Table 1, Figure 5). 
Table 1: Summary of in vitro and in vivo gene expression changes by FSWW08. In vitro investigation were conducted with normalized numbers of cells from cell line BT-474, purchased from the German National Resource Centre for Biological Material (DSMZ, Leibniz Institute DSMZ-German Collection of Microorganisms and Cell Cultures, Inhoffenstraße 7B, 38124 Braunschweig, G

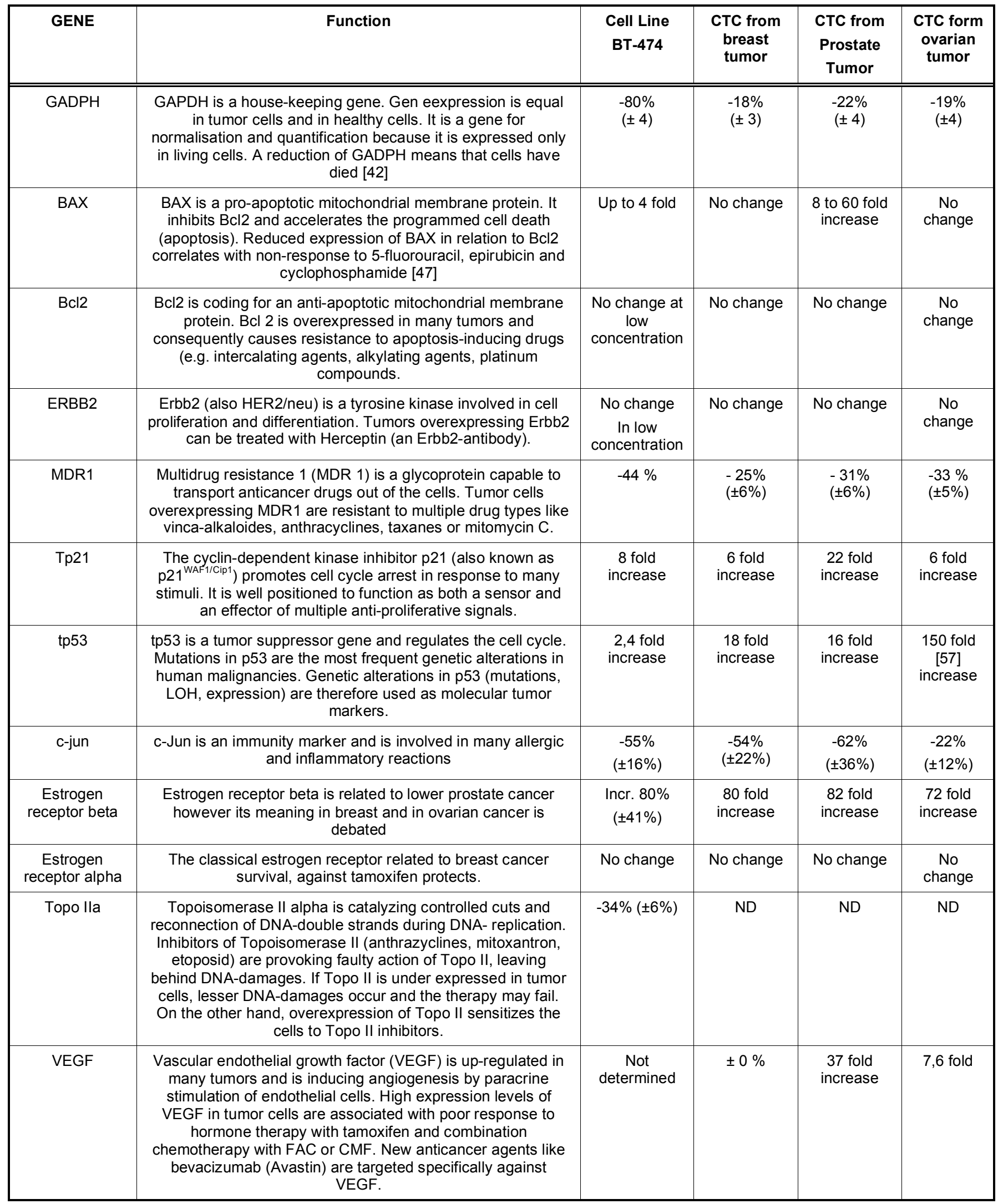




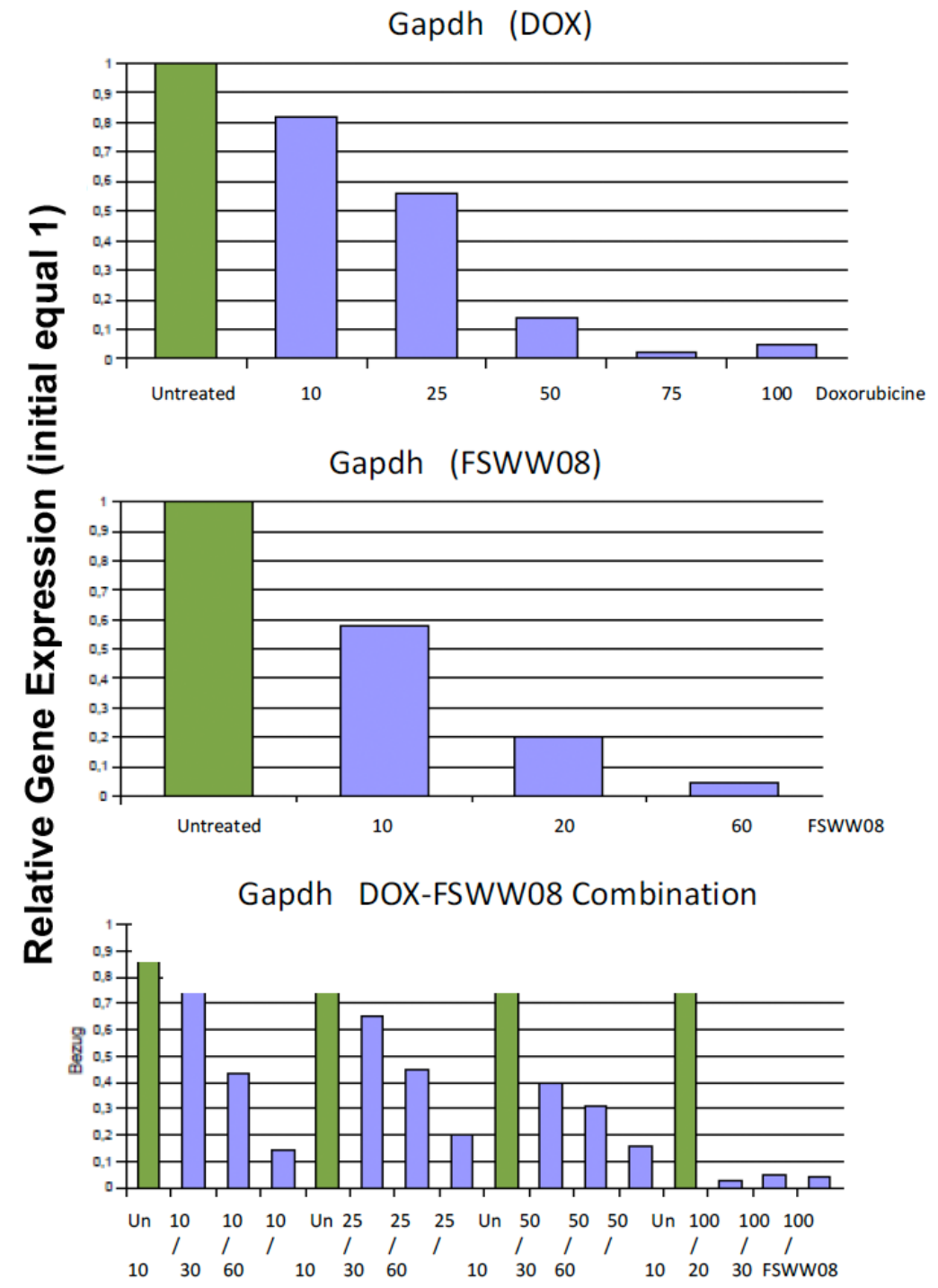

Figure 5: Effects of Doxorubicin and fermented soy (FSWW08) on the GADPH expression of cell line BT-474. GADPH gene expression of untreated cells expressed as 1.

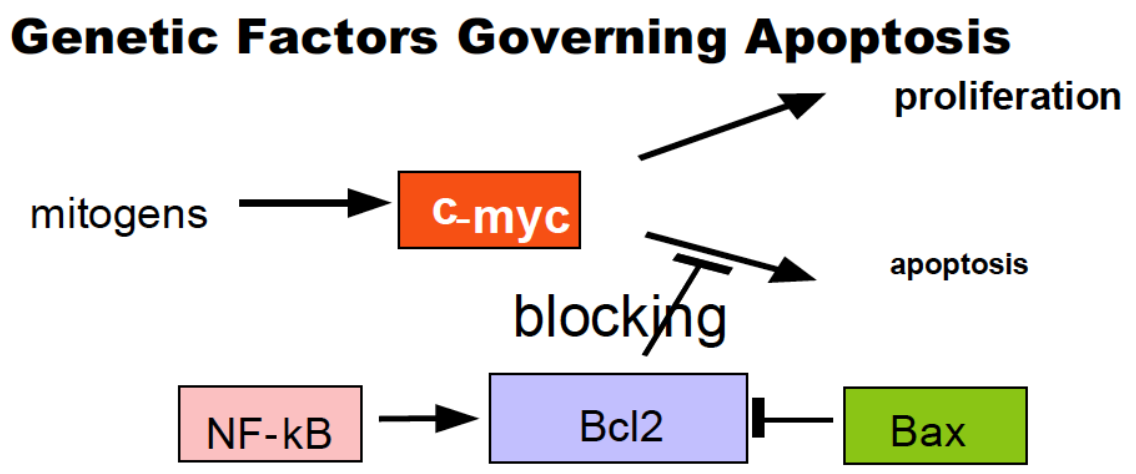

Figure 6: The role of c-myc, Bax and $\mathrm{Bcl} 2$ in apoptosis. c-myc: a regulator gene that codes for a transcription factor, a mutated version of which is found in many cancers. NF-kB: a protein complex that controls the transcription of DNA, important in stress, immunity and cancers.

Change in the gene expression of anti-apoptotic BCL2 (Figure 6): Doxorubicin: The effect of Doxorubicin on the expression of BCL2 was very strong. With increasing concentration of DOX the BCL2 expression values dwindled down to less than $10 \%$ of what was found in the untreated BT-474 tumor cells 
(only reported). FSWW08: FSWW08 had at low concentrations no effect on regulation of the antiapoptotic BCL2 expression values (Table 1).

BAX gene expression (Table 1, Figure 7). Doxorubicin had a low effect on the pro-apoptotic BAX expression (not shown here, only reported). Application of FSWW08 on the cell line BT-474 led to an increase of pro-apoptotic (Figure 6) BAX expression, and the increase of BAX expression was even higher: almost the 4-fold number was achieved compared to untreated tumor cells.

TOPO lla gene expression with increasing concentration of agents: Doxorubicin led to a 1.8-fold increase of TOPO lla gene expression, gene expression diminished again at high concentrations (Table 1). TOPO lla gene expression displayed only the 0.6 -fold value of untreated BT-474 cells. FSWW08 does not cause increase of TOPO Ila. On the contrary, it causes an up to 0.3-fold decrease (Table 1).

MDR1 (multidrug resistance) gene expression (Table 1, Figure 8), a marker of tumor resistance. An increase of Doxorubicin led to significant increase of the expression of the MDR1 gene, up to 17-fold increase in the gene expression of MDR1. The expression in the low concentrations of FSWW08 alone decreased by $40 \%$, comparable to untreated tumor cells.
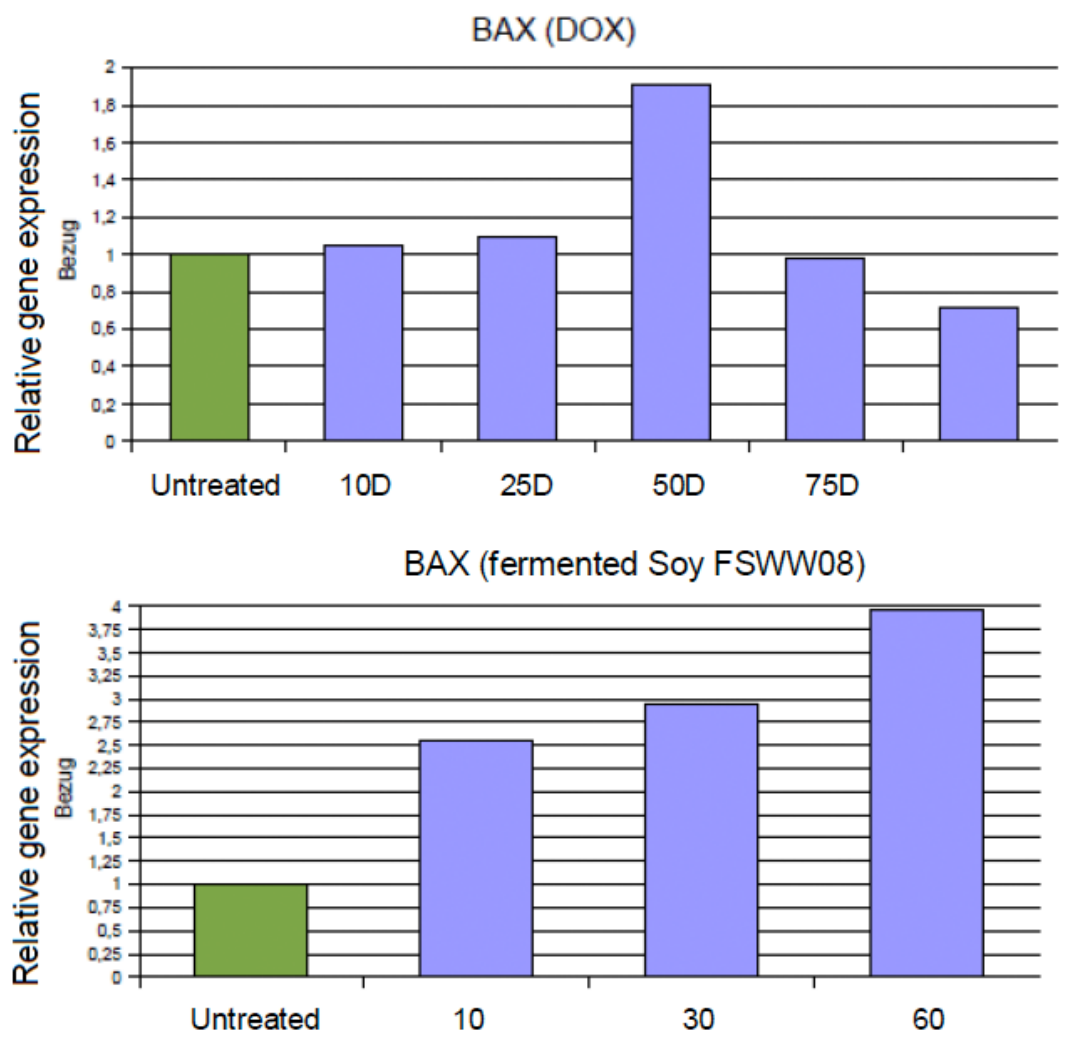

BAX (DOX/FSWW08

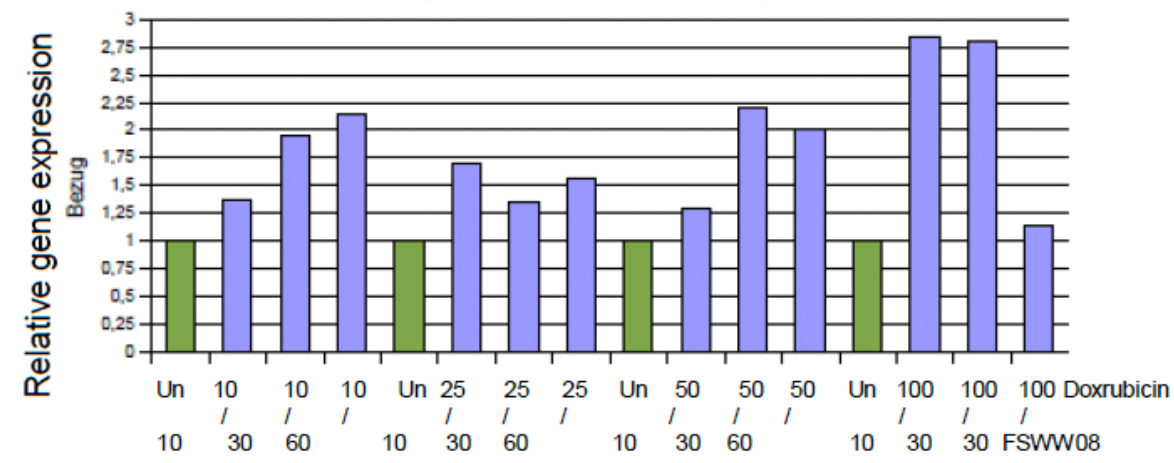

Figure 7: The effect of Doxorubicin (D) and FSWW08 on BAX gene expression in breast tumor cell line BT474. BAX gene expression of untreated cells expressed as 1 . 


\section{In Vitro Chemo}

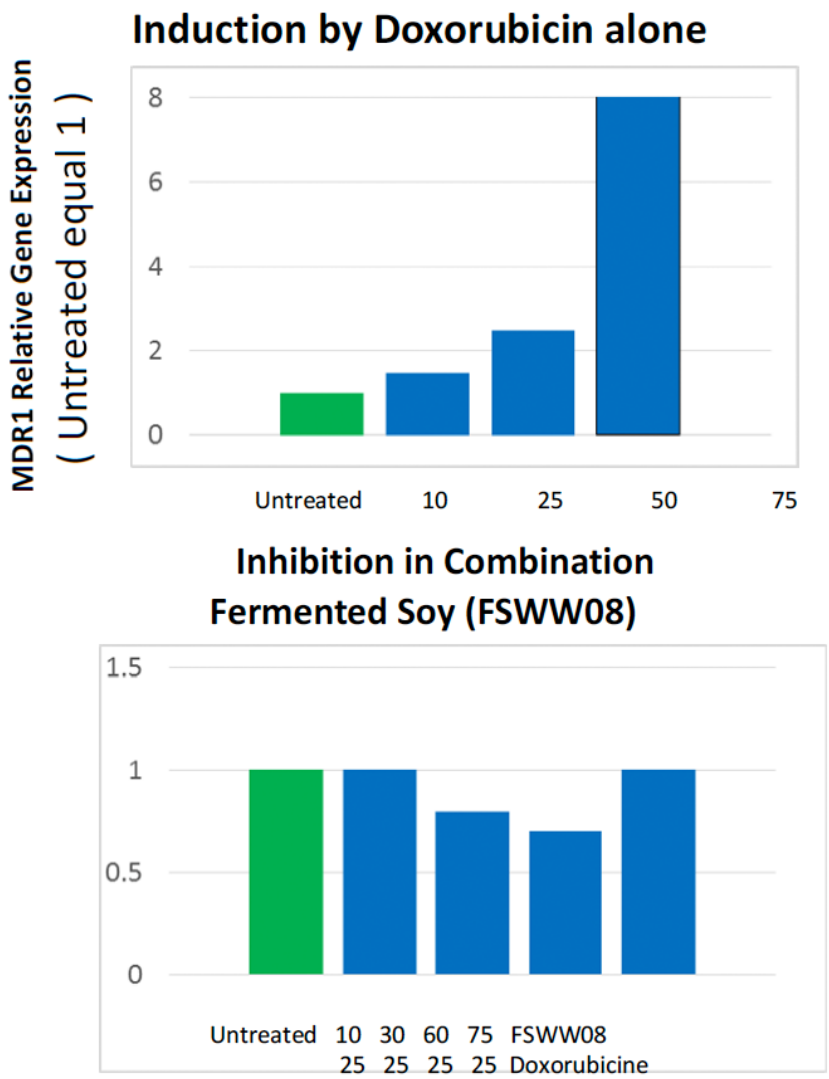

Figure 8: The effect of doxorubicin and fermented soy on MDR1 gene expression (multi-drug resistance) in breast tumor cell line BT474. MDR1 is a cell membrane protein that pumps substances out of cells. MDR1 gene expression of untreated cells expressed as 1 . Upper figure doxorubicin is added. Lower Figure doxorubicin is added and FSWW08 in increasing concentrations, denoted at the $\mathrm{x}$-axis.

\section{Combination of Doxorubicin and FSWW08}

With the low concentration of 10 DOX, an increasing concentration of FSWW08 also caused an up regulation of the expression of MDR1. With 10 DOX/60 FSWW08 it was possible to achieve an expression corresponding to a 60 FSWW08 mono therapy. A high concentration of Doxorubicin 100 DOX combined with $10 \mathrm{HAL}$ had an effect comparable to Doxorubicin mono treatment. Increasing the amount of FSWW08 (10, 30, 60 FSWW08) caused a decrease in the expression of MDR1.60 FSWW08 had the effect of a 3-4-fold increase while the available amount of 100 DOX would have caused a 17 -fold increase in mono therapy. Apparently the effect of one of the two agents on the MDR1 gene prevailed. If Doxorubicin and FSW008 were given in average concentrations, no increase in MDR1 gene expression was achieved. This means that at low physiologic concentrations fermented soy bean (FSWW08) eliminates drug resistance caused by doxorubicin.

\section{ERBB2 Gene Expression}

Doxorubicin alone caused a continuously decreasing ERBB2 expression (not shown here, only reported). While at low concentrations for DOX is still more than 0.7 times of untreated BT-474, higher DOX concentrations already down regulates this receptor tyrosine kinase by 10 times (Table 1).

\section{Estrogen Receptors Alpha and Beta Gene Expression}

Estrogen receptor alpha is the classical Estrogen receptor alpha to describe breast cancer risk. As can be seen in Table 1, FSWW08 did not change Estrogen receptor alpha gene expression, but did statistically significantly increase Estrogen receptor beta gene expression (Figure 9).

ER- $\alpha$ and $-\beta$ Gene Expression in Tumor Cells extracted from Prostate Cancer Patients Blood After Consumption of Fermented Soy (FSWW08)

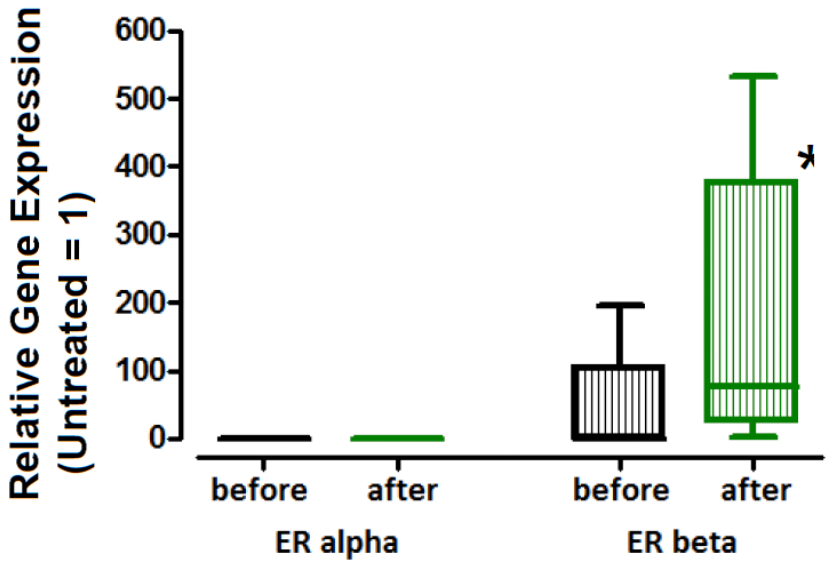

Figure 9: Circulating Tumor Cells (CTCs) of prostate cancer patients were analyzed for expression of ER-alpha (Estrogen receptor-alpha) and ER-beta, $\mathrm{n}=6$ mean and SEM. Asterisk denotes differences reach statistically significant different on a $5 \%$ probability level.

Gene expression studies with from blood extracted CTC from cancer patients (Table 1). Table 1 compares several gene expression investigations obtained by oral consumption of fermented soy bean FSWW08 after 3 month consumptions with those seen in vitro cell culture. Estrogen receptor alpha and beta (Figures 9,10): In agreement with in vitro experiments, Estrogen receptor alpha was not increased in CTC of prostate, ovarian, and breast cancer, however Estrogen receptor beta (Table 1).

\section{BAX / Bc/2 Gene Expression}

The BAX / $\mathrm{Bcl} 2$ ratio is statistically significantly raised in CTC of prostate cancer patients, however not in ovarian and breast cancer in vivo (Table 1, Figures 
11-13), suggesting that FSWW08 increases a proapoptotic state of CTC in prostate cancer. BAX was increased in vitro in breast cancer cells, suggesting a pro-apoptotic effect as well (Table 1).

ER- $\alpha$ and $-\beta$ Gene Expression in Ovarian Tumor Cells extracted from Blood of Patients

After Consumption of Fermented Soy (FSWW08)

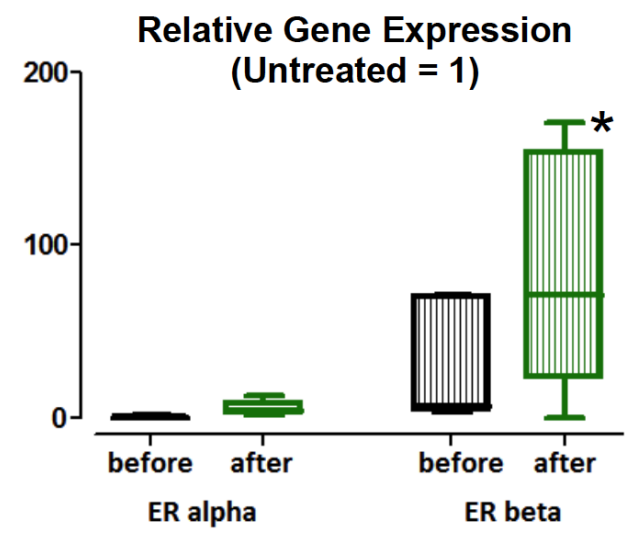

Figure 10: Circulating Tumor Cells (CTCs) of ovarian cancer patients were analyzed for expression of ER-alpha (Estrogen Receptor-alpha) and ER-beta $n=5$ (mean and SEM). Asterisk denotes differences reach statistically significant different on a $5 \%$ probability level.

Apoptosis Marker (Bax/ $\mathrm{Bcl}_{2}-$ Ratio) in Blood Circulating Prostate Cancer Cells altered by Fermented Soy (FSWW08) Individual Cases

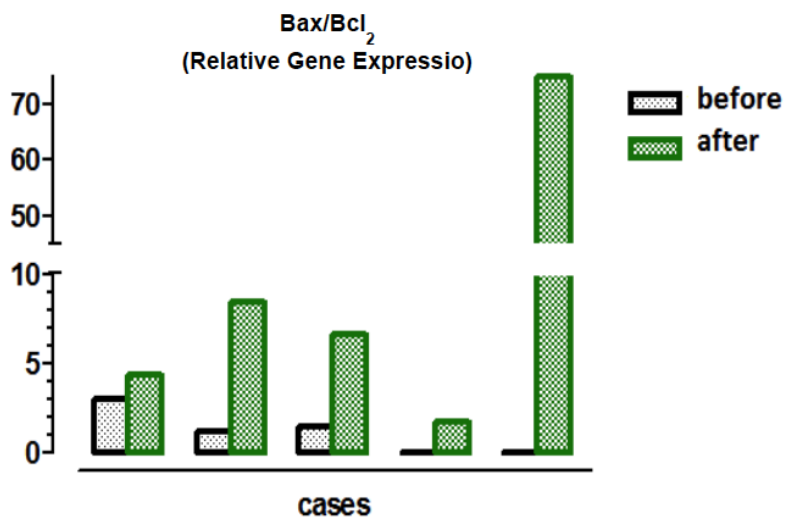

Figure 11: CTCs (circulating tumor cells) in prostate cancer patients showed an increased gene expression ratio of apoptosis-triggering genes $\mathrm{Bax} / \mathrm{Bcl} 2$ ratio after FSWW08 (fermented soy) therapy.

GAPDH gene expression: All three different CTC from breast, prostate, and ovarian cancer patients are decreased (Table 1), although somewhat smaller than in vitro.

\section{Tp53 Gene Expression}

tp53 protein function is considered a gate keeper and hall mark for cell repair and controls many important markers in cancer, as well as cell cycle arrest
Apoptosis Marker (Bax-Bcl 2 - Ratio) in Blood Circulating Mamma Tumor Cells $(n=7)$ before and after Consumption of Fermented Soy (FSWW08)

\section{Relative Gene Expression (Untreated $=1$ )}

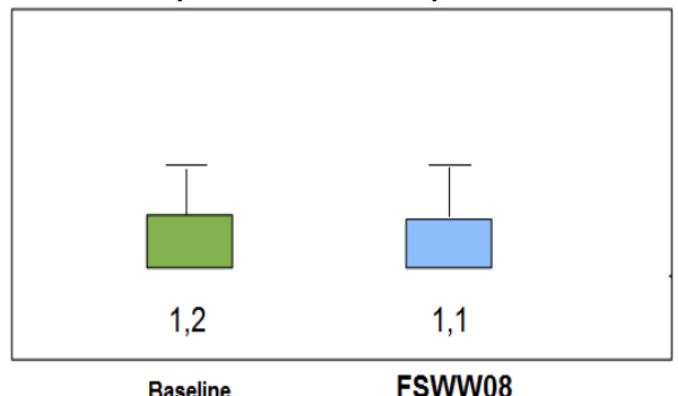

Figure 12: CTCs of mama cancer patients showed no change of gene expression ratio of apoptosis-triggering genes $\mathrm{Bax} / \mathrm{Bcl}_{2}$ after FSWW08 consumption. (Mean and Standard deviation). Average are not statically significantly different on a $10 \%$ level of significance.

No statistically significant Change Apoptosis Marker (Bax- $\mathrm{BCl}_{2}-$ Ratio) by Fermented Soy FSWW08 in Blood Circulating Ovarian Tumor Cells $(n=5)$

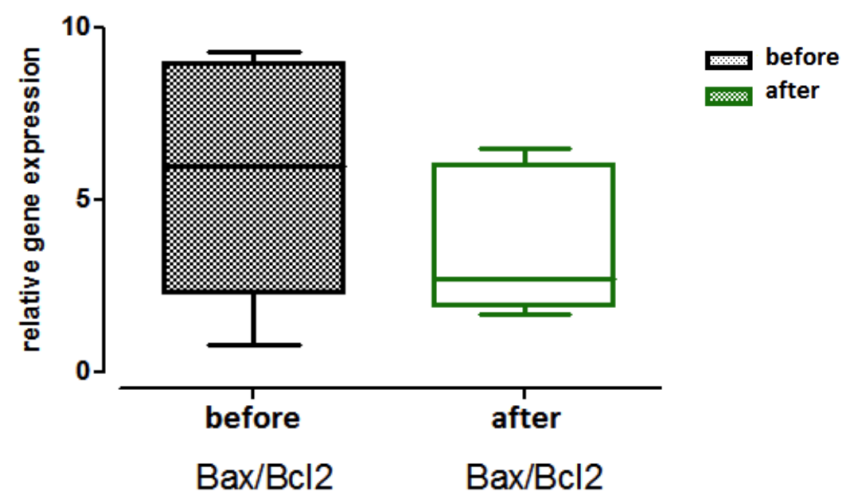

Figure 13: CTCs of breast cancer patients showed no change of gene expression ratio of apoptosis-triggering genes bax/bcl2 after 100 days of FSWW08 (fermented soy) therapy. (Mean and Standard error of the mean; $(n=5)$. Mean values are statistically not significant on a $5 \%$ level of significance.

(Figure 14) and apoptosis. Mutation of tp53 and loss of gene expression have been detected in many cancers. It was found that gene expression of tp53 in CTC was increased in vitro a well as in vivo (Table 1, Figure 15). The increase in CTC was rather pronounced, suggesting that in the in vivo case, either additional mechanisms occur in CTC or fermented soy may cause additional effects. As is depicted in Figure 15, tp53 gene expression is sustained over several years.

\section{Tp21 Gene Expression}

tp21 is also a key protein in cell repair controlling apoptosis and cell cycle arrest. It may act together with 


\section{The Tumor Suppressor Factors p21 and p53}

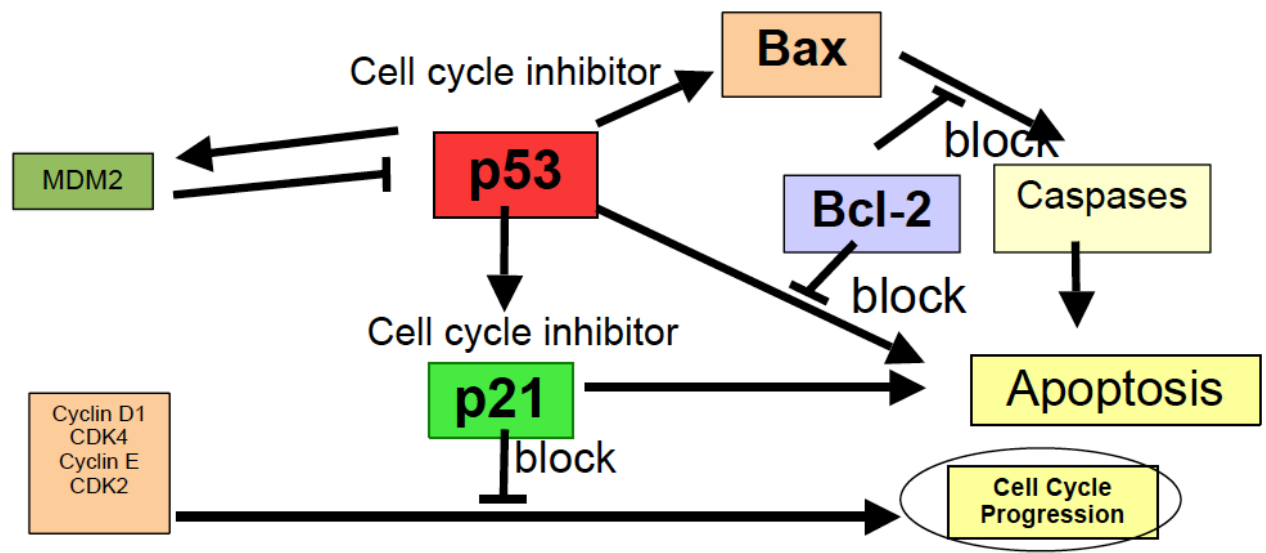

Figure 14: Schematic representation of the relationship between tumor suppressor factors p21 and p53 and their involvement in apoptosis and cell cycle progression.

\section{Tumor Suppressor Factor p53 Gene Expression in CTC After Consumption of fermented Soy (FSWW08)}

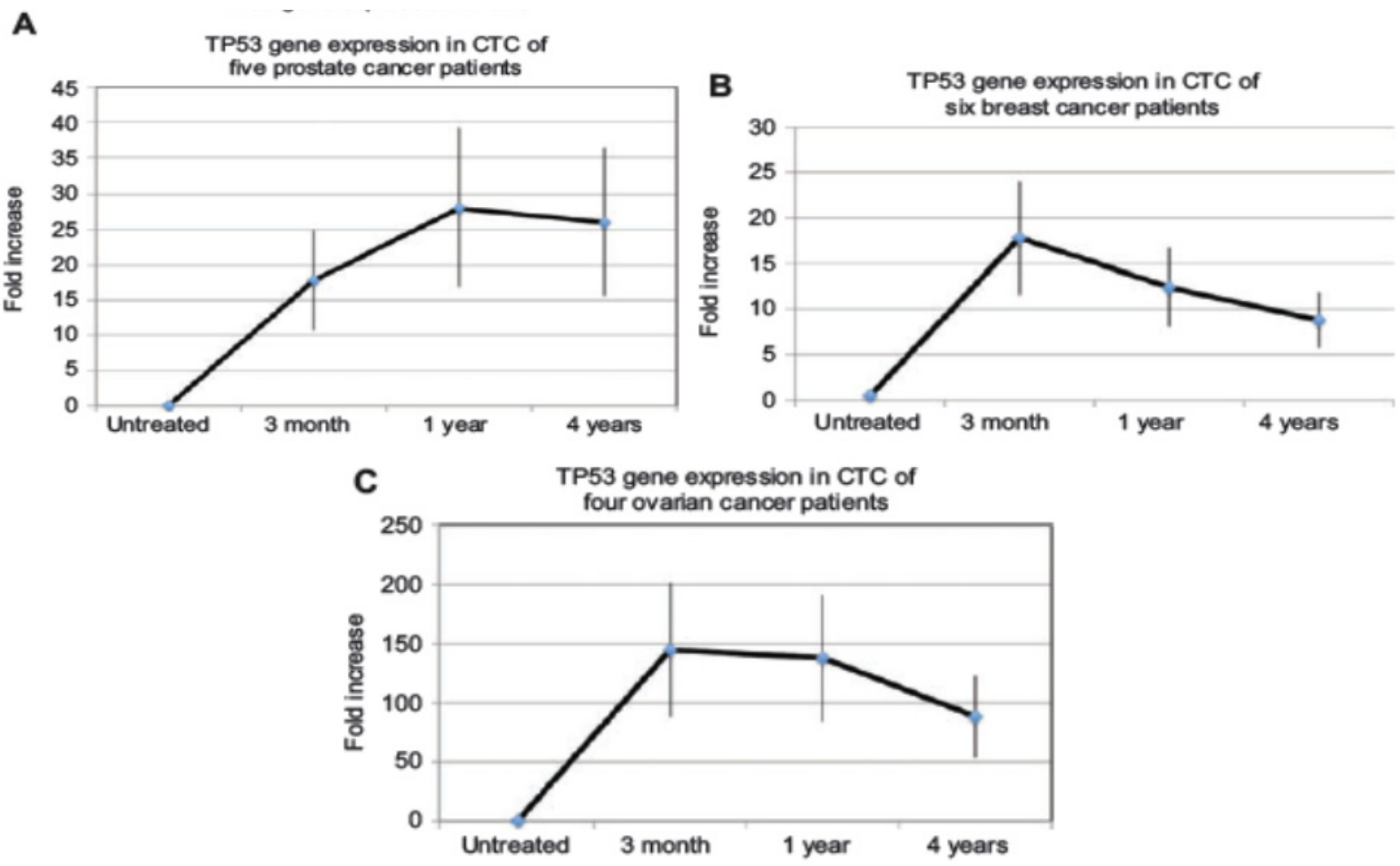

Figure 15: Relative gene expression changes of in-blood circulating cancer cells ovarian cancer patients compared to baseline, compared to expression after 1.5 months, after 3 months and after 4 years (A) prostate cancer patients, (B) breast cancer patients (C) ovarian cancer patients. Numbers denote individual patients. Taken from ref [11]. All average levels after consumption reach statistically of significance on the $5 \%$ level of significance.

p53 and is important in controlling cancer (Figure 14). Tp21 is increased rather strongly in vitro as well as in vivo in CTC. Clearly, the effect of FSWW08 on CTC is more pronounced than in vitro in all tumors (Table 1, Figures 16-18).

\section{MAPK}

The expression of the MAPK (Figure 19), was positively altered by FSWW08 in breast cancer cells. Additionally reduced inflammation in cancer was detected with conventional staining technique, 


\section{Cell Cycle Inhibitor P21 is Increased in Blood Prostate CTC by Fermented Soy FSWW08}

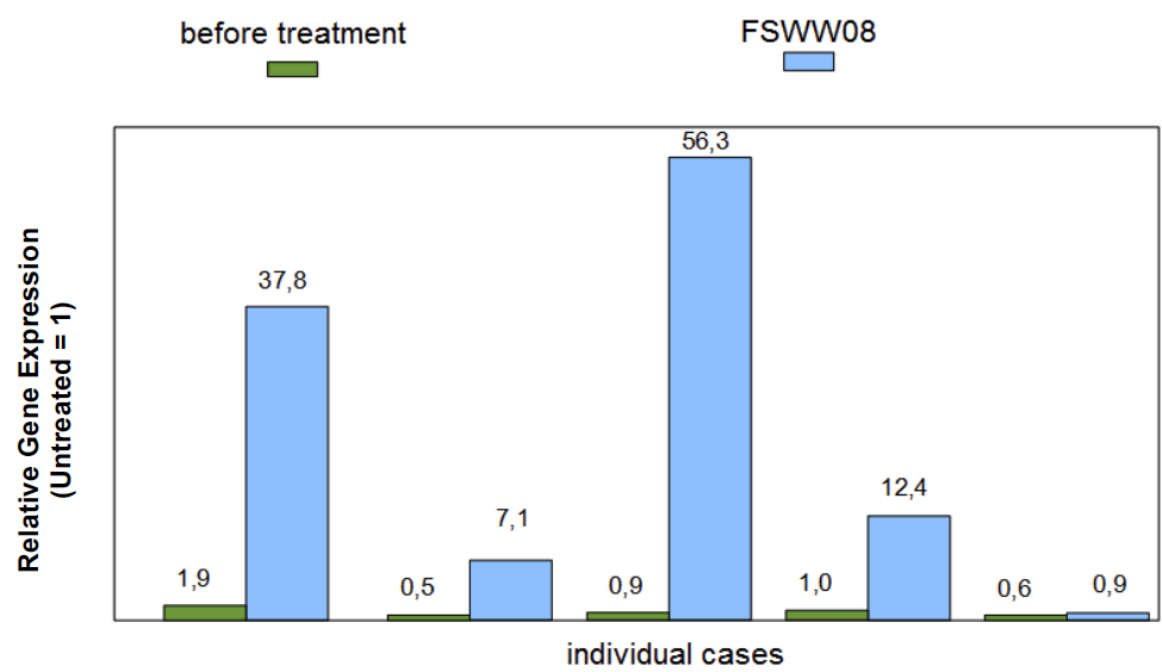

Figure 16: Individual relative gene expression changes of tumor suppressor factors p21 in blood CTC (circulating tumor cells), of prostate cancer patients.

Gene Expression of Cell Cycle Inhibitor P21 is Increased by fermented Soy

(FSWW08) in CTC Extracted from Mamma CA Patients

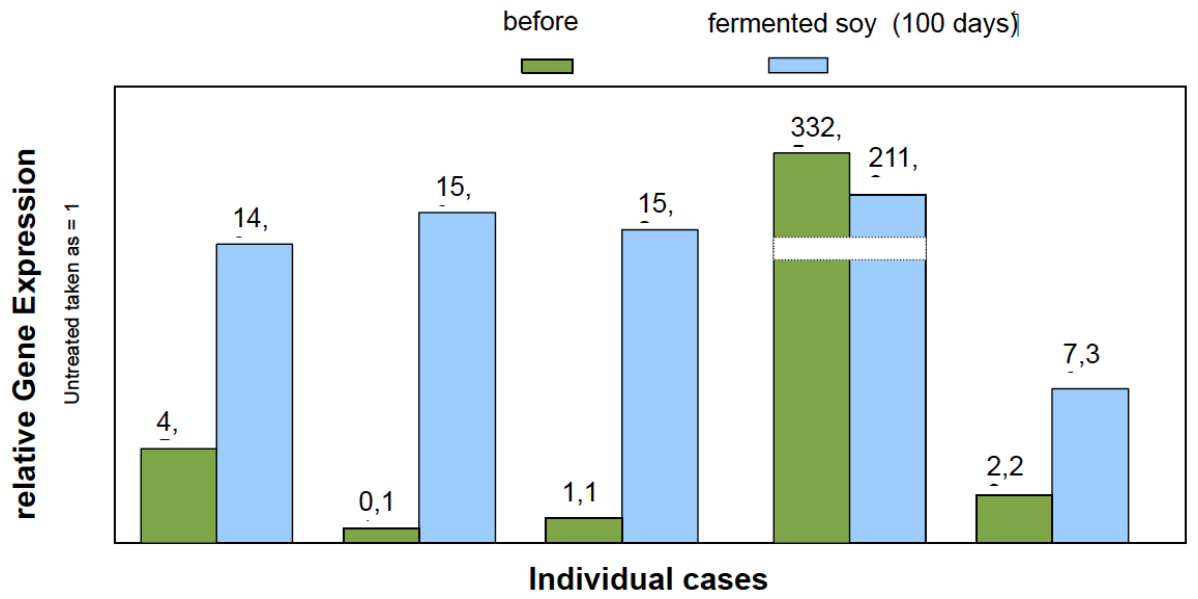

Figure 17: The gene expression of tumor suppressor factors p21 in blood CTC of mamma cancer patients $(n=7)$.

corroborating the gene expression results (Figure 20), where a histological tissue sample of a breast cancer patient was excised and stained. The conventional staining technique supports the genetic findings that immunity is favorably increased in the tumor.

\section{c-Jun Gene Expression}

The intracellular release of cytokines in asthma or allergic reactions is linked to increased c-Jun kinase, p30 MAP-kinase and NFKB in local immune cells [12]. The first-generation antihistamines have similar immune modulating responses to FSWW08 and dexamethasone shares similar ability to alter the gene expression of p38, MAPkinase, c-Jun and NFKB in myeloma cells, prostate, breast and ovarian cancers [40]. The reduction of C-Jun in CTC extracted from Breast tumors supports the findings that immunity is increased (Figure 19).

It is believed that the decline of TNF alpha in the blood of patients (Figure 21) is caused by improved barrier function, so that larger molecules cannot permeate the cellular barrier (Figure 22). The reduction in cachexia (Figure 23) by fermented soy bean may very well be related to improved barrier function, documented by the improvements of matrix metalloproteinase 9 gene expression [24]. 
Gene Expression of Tumor Suppressor Factor P21 is induced by

Fermented Soy in Blood CTC of Ovarian Cancer Patients

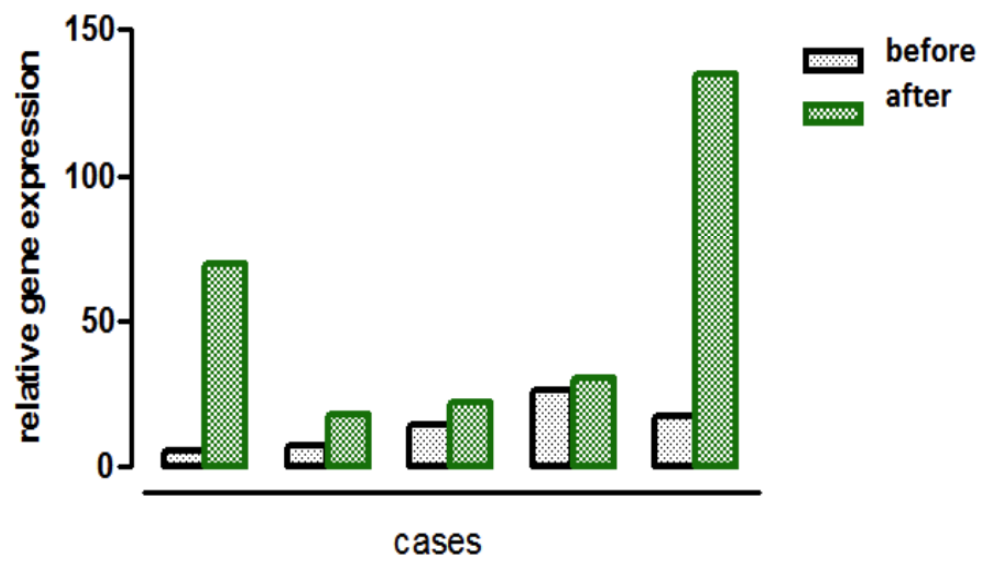

Figure 18: The individual relative gene expression of tumor suppressor factors p21 in blood CTC extracted form ovarian cancer patients $(n=5)$.

\section{The Influence of fermented Soy Consumption on MAP-Kinase Cascade Gene Expression on CTC Extracted from Blood of Mamma Ca Patients}

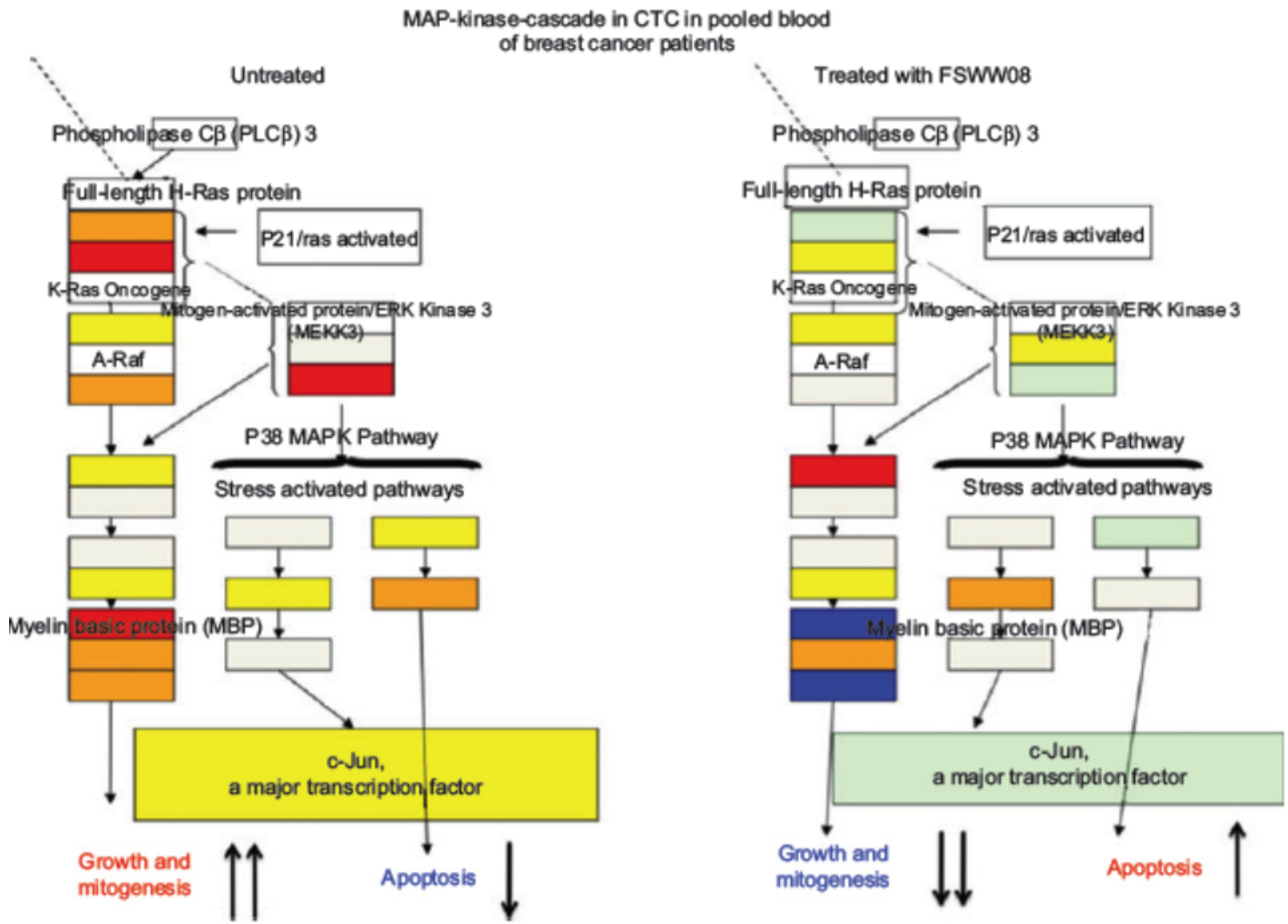

Figure 19: Gene expression changes by fermented soy (FSWW08) on blood circulating tumor cancer from breast cancer cells. The cells were extracted from pooled blood. $\square>2, \square 1.5<x<2, \square 1.0<x<1.5, \square$ no change, $\square 1>x>0.66, \square 0.66>x>0.5, \square>5$.

\section{VEGF Gene Expression}

As is depicted in Figure 24, a statistically significant increase of VEGF gene expression was detected in CTC extracted from prostate and ovarian cancer patients.

\section{Clinical Effects}

In cancer patients, appetite and immune status are significantly weakened. A fermented soy formulation FSWW08 (group A, consumed FSWW08 orally) and a placebo formulation (group B) was tested in a clinical 


\section{Reduction of Angiogenesis and DNA Activity in a Breast Tumor of a pregnant woman after consumption of fermented soy (FSWW08) \\ Depicted with Conventional Histological Markers}

$\mathrm{H} \& \mathrm{E}$
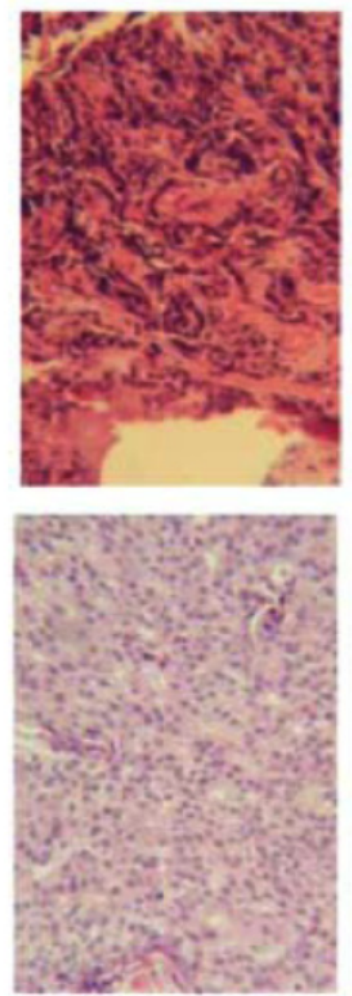

F8
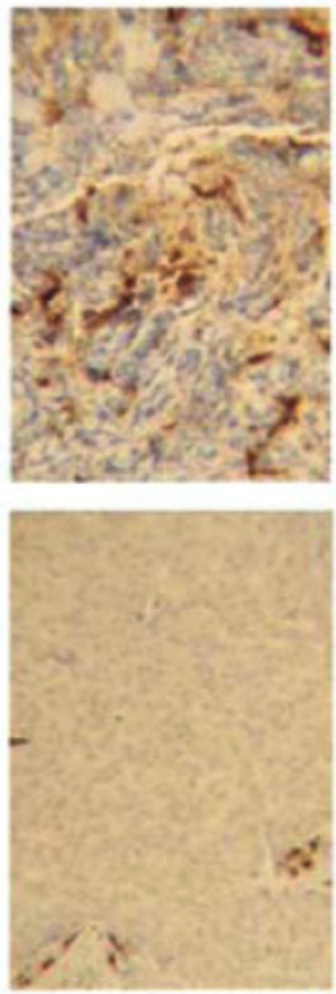

Ki67
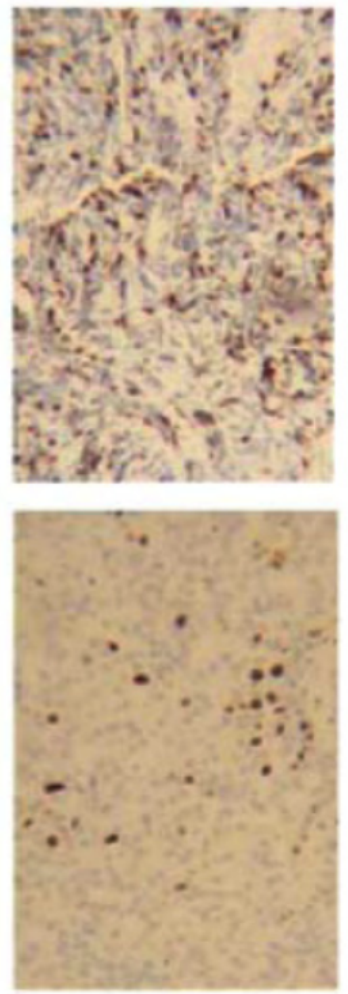

Figure 20: Histology of a breast cancer sample of a 38-year-old woman. Upper row was taken before consumption and lower row was taken 14 days later. "H\&E" denotes hematoxylin and eosin. Hematoxylin and eosin stain is frequently used for routine tissue preparation. Eosin is an acid aniline dye. It binds to and stains basic structures (or negatively charged structures), such as cationic amino groups on proteins. It stains them pink. It can be interpreted as DNA activity and the loss of color as a reduced DNA activity. F8 as a vascular marker is discussed by Folkman [79]. KI67 is a common marker of anti-angiogenesis. Taken from ref. [38].

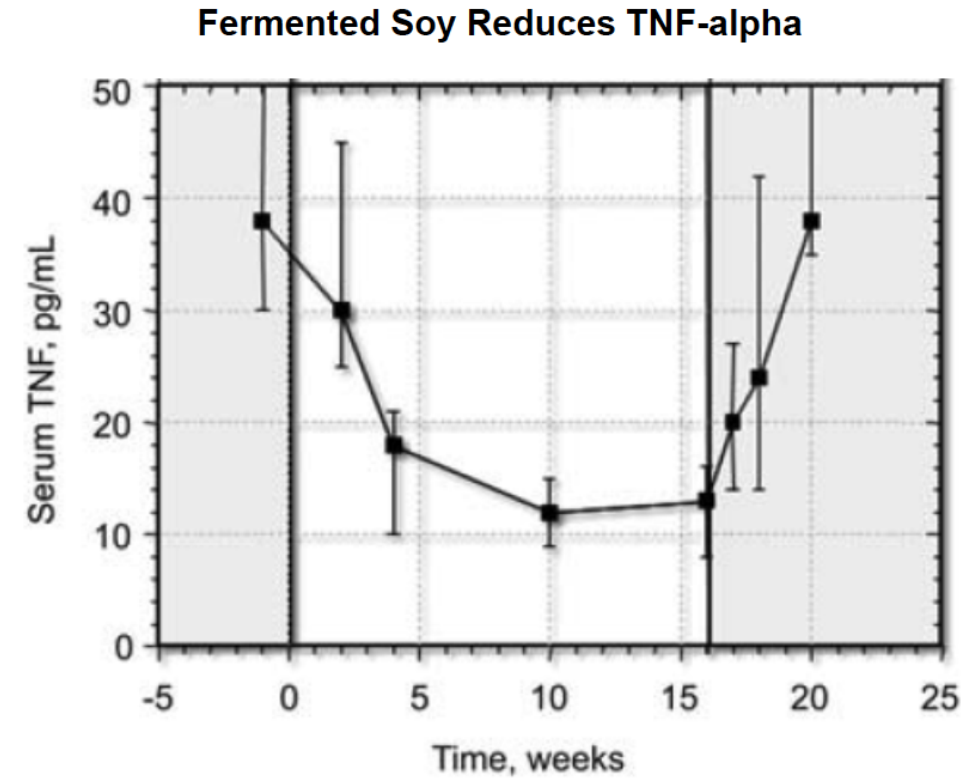

Figure 21: TNF-a blood levels before, during, and after daily consumption of fermented soy. Taken from ref [28]. 


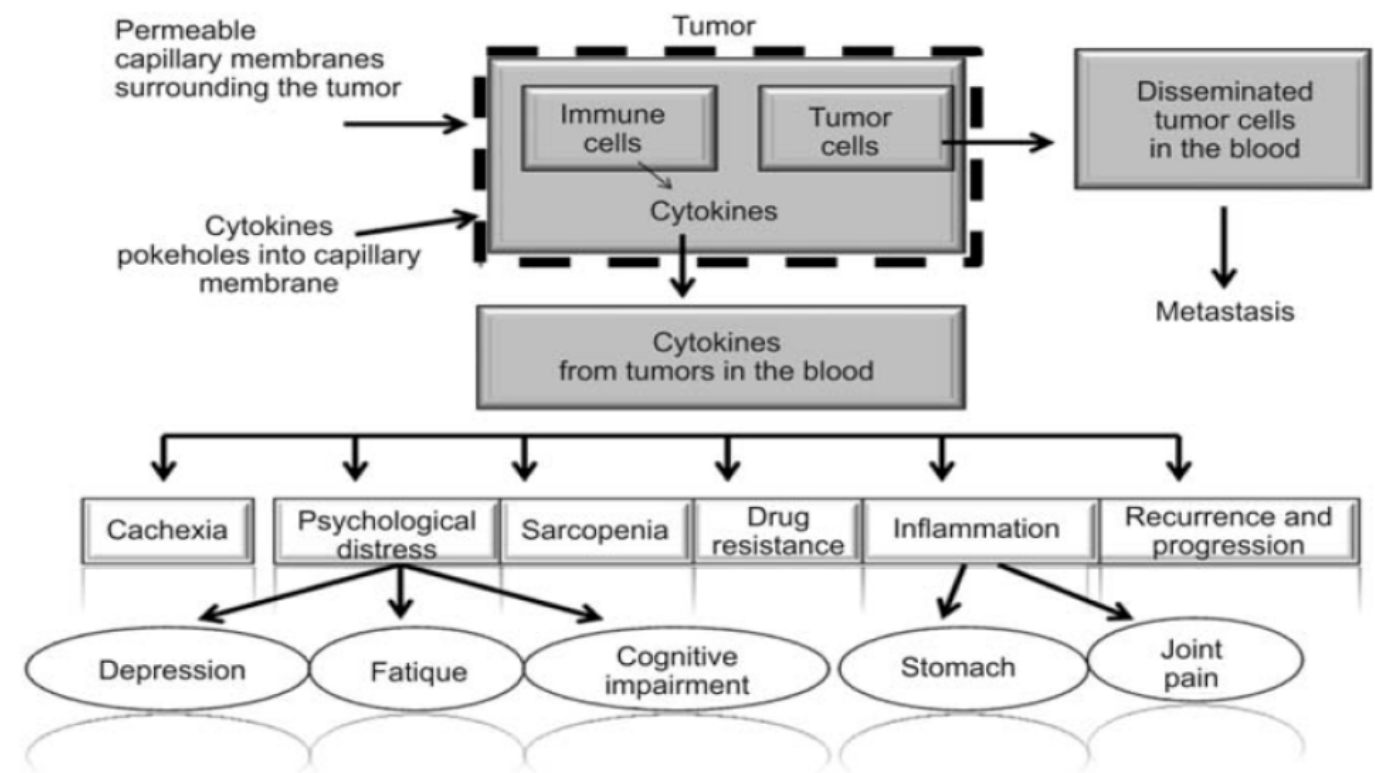

Figure 22: A conceptual model of cytokines in cancer. Cancer and immune cells are sources of cytokines, which support the growth of cancer and lead to psych behavioral symptoms (fatigue, depression, and cognitive impairment), drug toxicity, drug resistance, anorexia and cachexia, pain, and cancer recurrence and progression. Genetic background, cancer treatment, and psychological distress can corroborate the production of cytokines. In cancer survivors, hyperactive immune cells might be the major source of cytokines in psych behavioral symptoms. Taken from ref: [28].

Cachexia in Cancer Patients after Chemotherapy (With and without Protection by Fermented Soy, FSWW08)

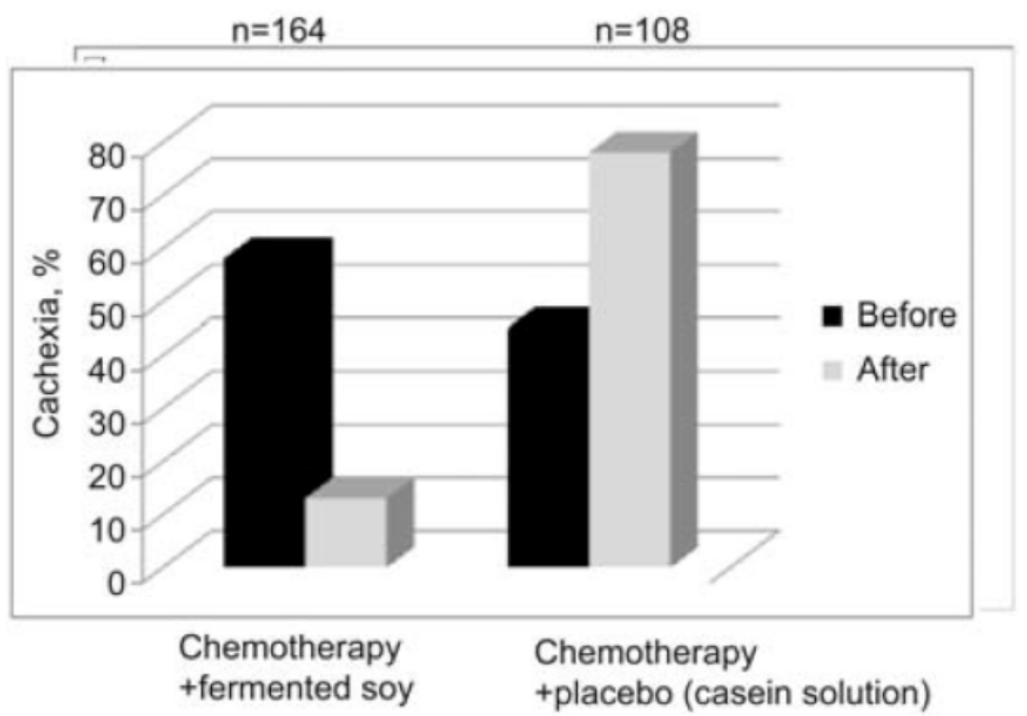

Figure 23: Influence of daily consumption of a fermented soy formulation on appetite loss (cachexia) in cancer patients under chemotherapy compared to a group receiving placebo solution containing casein. This was a double-blind study Ref [27].

study, conducted in six cancer hospitals where cancer patients underwent radio or chemotherapy (patients undergoing radiation therapy $\mathrm{n}=78$, patients undergoing chemotherapy $n=184$, total 262) [39] (Figure 23). Group A experienced statistically significant increases in lymphocyte transformation rates, whereas group B did not (Figure 25). Formulations A inhibited or lessened statistically significant decreases in white blood counts, whereas the placebo group experienced substantial decreases. Hemoglobin and platelet decreases were inhibited in group A, although not statistically significantly [39]. Patients in group A received no blood transfusions, whereas many patients from the placebo group received blood transfusions undergoing chemotherapy (Figure 24). Appetite loss was reduced in group A from $57.9 \%$ to $13.3 \%$. In the placebo group, an increase in appetite loss was detected under chemo- and radiation 


\section{VEGF gene expression (untreated as 1)}

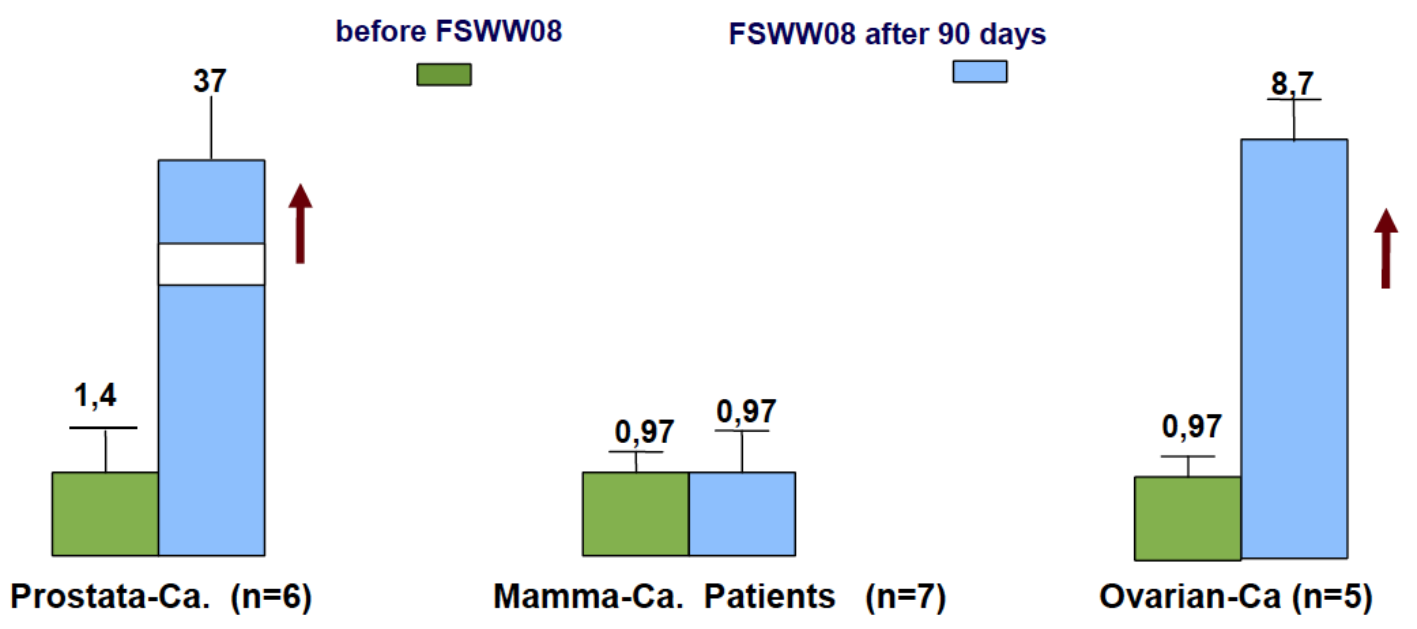

Figure 24: VEGF gene expression in circulating tumor cells extraxted from patients.

\section{Reduction of Chemotherapy induced Leukocytopenia by Fermented Soy (FSWW08)}

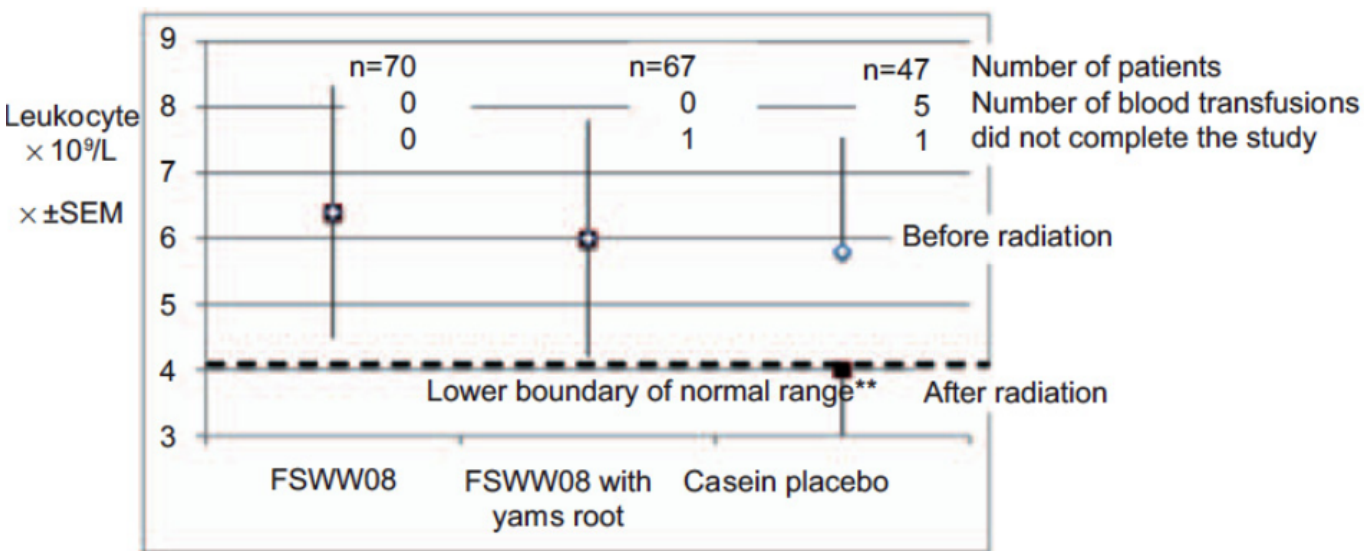

Figure 25: Mean and standard deviation of leukocytes before (grey-filled squares) and after (black-filled squares) chemotherapy with FSWW08, or FSWW08 with yam root extract or a casein placebo solution. Dashed line limits lower range of normal range. ${ }^{* *}$ Denotes a statistically significant difference on the $p<0.01$ error level of significance. Taken from ref [27].

therapy from $41.8 \%$ to $70.9 \%$ (Figure 26). This study was conducted in China, but similar results were obtained in the USA at Harvard Medical School [44].

FSWW08 caused in a small pilot study a higher survival of ovarian cancer patients compared to standard therapy, although not statistically significant [40]. All prostate cancer patients treated with FSWW08 are still alive [40]. The survival of breast cancer patients increased and the survival rate under consumption of FSWW08 can be related to breast cancer patients with high gene expression of tumor suppressor factor p53, which also show a higher survival rate than compared to those without it.

\section{DISCUSSION}

The World Health Organization (WHO) reported that cancer causes $63 \%$ of deaths worldwide and is the second cause of death in western countries [45]. Cancer is a complex genetic disease with alterations in multiple cellular signaling pathways [46]. Two traits are shared in most cancers: genome instability and mutation tumor-promoting inflammation in the surrounding tissue so that the tumor can grow into surrounding tissue [47]. Chemotherapy against the tumor is mostly conducted with agents inhibiting mitosis or by other cell toxic mechanisms, for example with doxorubicin [48]. Only recently it was found that plants 


\section{Schematic Comparison of Tumor and Parasite}

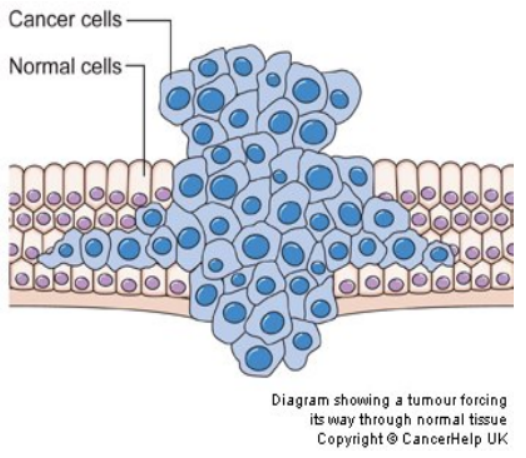

Cancer growth into tissue
Powdery Mildew on Columbine leaf Eyisiphe spp.

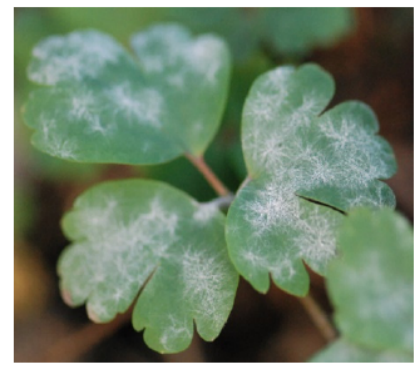

Parasite growth into a plant

Figure 26: Schematic comparison of similar growth pattern of a cancer into tissue and a parasite into a leaf.

regulate cell growth similar to animals and humans [78]. Animals developed later in the evolutionary development other gene regulating compounds like the steroidal hormones, where estradiol was the first steroidal hormone (and was later diversified into the hormone cascade [79]).

Plants protect themselves against the growth of a parasite, what is mechanistically similar to a growth of a tumor into a surrounding tissue (Figure 26), by DNA repair mechanism, what is defined as environmental biotic stress [29]. It is of interest that a tumor may be mechanistically defined as an unwanted intruder that imposes stress on its tissue environment to facilitate its growth (Table 2, Figure 26). Only recently plant scientists have revealed that many agricultural plants protect themselves against environmental drought stress and injuring yeasts or parasite by similar repair DNA mechanisms, which exist in humans too, like MAPkinase (Table 2, Figures 4, 19). Hormones and small RNA actively alter the genomes within a plant and they have even the capability to conduct this in other species too, because it was shown that soybean can pass protective genome mechanism to other plant species too, raising the question whether this mechanism can protect against cancer too [37].

The clinical importance of stress repair mechanism and the difference to chemotherapy may be illustrated by the fact that the fermented soy formulation discussed here in this study caused also a strong and long lasting reduction of mental stress in soldiers suffering from PTSD, the posttraumatic stress disorder [49]: Severe mental stress is a characteristic of PTSD and cellular and mental stress are related [50]. The same fermented soy bean formulation has been shown clinically in humans to stabilize Amyotrophic Lateral Sclerosis, ALS, what is by definition a progressive cell disease [82]: Although no complete normalization was attained, an inhibition of the progressive state was

Table 2: Comparison of cellular gene markers and hormones related to cancer compared to gene described in the plant as a cell repair gene and determined in plant biology. All genes were determined in soy with the exception of VEGF like genes and protein. This was found in almost all species with larger tissue besides yeasts. Foe explanation see text and literature quotation and Figure 4

\begin{tabular}{|c|c|}
\hline $\begin{array}{c}\text { Plants } \\
\text { Biotic Stress Defense }\end{array}$ & $\begin{array}{c}\text { Human } \\
\text { Cancer Markers }\end{array}$ \\
\hline \hline SUPPRESSOR OF GAMMA RESPONSE 1 (SOG1) & Tp53, Tp21 Human Cancer \\
\hline NO production control via glutathione peroxidase, phenylalanine-ammonia lyase (PAL), and \\
PR - 1, genes (ref [81]) & BAX \\
\hline BAX & VEGF \\
\hline VEGF/PDGF (platelet-derived growth factor) group of the cystine-knot superfamily. (Ref [80]) & MAPkinase \\
\hline MAPKinase [30] & MMP \\
\hline Matrix metalloproteinases (MMP (ref [29]) & C-JUN \\
\hline C-JUN & \\
\hline
\end{tabular}


seen over several years and for the first time ever. As was outlined above this plant cell repair mechanism through abiotic and biotic stress response is non-toxic and no side effects were reported in cancer multicenter trial studies and in the ALS study conducted with the same fermented soy bean formulation, tested here in vitro gene expression studies.

Clinical improvements in cancer patients, relating to mental and cellular stress, have been reported previously by other authors too, investigating the soy ingredient isoflavone genistein, which resulted in increased patient survival time, better quality of life, and reduced adverse effects related to cancer chemotherapy delivering a dose of 1000 to $1200 \mathrm{mg}$ Isoflavones a day [51]. We previously reported also that fermented soy bean (FSWW08), which reduced stress and improved well-being in soldiers, increased quality of life in cancer patients as well, reducing cachexia (Figure 22), reduced side effects of cancer treatment like cachexia (Figure 23) and leukocytopenia (Figure 25) and increased the survival time of cancer patients [40].

A direct comparison of gene expression changes by FSWW08 formulation was conducted by comparing the effect on cancer tumor cells (CTC) extracted from blood of cancer patients to in vitro cancer cell line treated with cytotoxic doxorubicin (Table 1). Gene expressions were conducted with the same protocol, method, and the same laboratory. On the other side CTC of breast cancer patients and the in vitro breast cancer cell line are not from the same donor population. Also, CTC subpopulations might exist with different properties, because cancer cells having the ability to form micro metastases and metastases are likely emerge from CTC, a high medical need exists to develop new methods to characterize the genotype and phenotype of CTC [11]. Although we have not investigated whether subpopulations in our CTC exist, the alterations by fermented soy bean formulations were pronounced.

Comparisons of gene expression cancer marker by fermented soy bean in CTC with the breast cancer cell line BT shows that many anticancer effects like increase of BAX, increase of tp53, c-Jun, tp21, silencing of MAPkinase are increased in a similar manner in vitro cell lines and in CTC (Table 1). This investigation corroborates other in vitro investigators, who also saw an improvement of tp53 gene expression in vitro [51], as well as MAPkinase [52], NF-KB [38], matrix metalloproteinase [53-55], investigating soy ingredients.
This here presented investigation is unique since for the first time ever gene expression in circulating tumor cells extracted from patient blood are represented and are additionally related to new findings in the area of genetic plant science (Table 2), where plants show a mechanism for cell repair under stress not using any toxic mechanism.

A very important finding is the simultaneous increase of tp53 and tp21 gene expression in CTC, which corroborates the strong apoptotic effect of fermented soy bean formulation, because tp53 reduces cell cycling, increases cell repair and diminishes cellular stress (Figure 14) [56, 58]. Modification and loss of tp53 has been described as a hall mark for cancer and missing in about $50 \%$ of all cancer patients [51]. Clearly, there are differences between in vitro and in vivo: in vivo CTC cells have to be considered to be less differentiated, so that the increase of tp21 and tp53 gene expression may have been more pronounced in vivo (Table 1). Tp53 is related to increased apoptosis of white blood cell formation too [56], which we saw in our clinical experiments (Figure 24). Only recently it was found that plants do express very similar repair genes to tp53 to overcome environmental stress [29].

The additional improvement in barrier function documented by increase of matrix metalloproteinase gene by soy by us and others $[39,55]$ in combination with strong increase in immunity (Figure 20) may very well explain the reduction in cancer side effects through inhibiting cytokine release from the tumor into the blood (Figure 23) but also modify the cancer stem cells (CSC) in the tumor, which are believed to drive cancer growth and metastasis. Improving barrier function of plants may be an important mechanism by plants to protect themselves against parasites, injuries, and cuts and they may not have lost its ability when applied in humans.

A special fermented soy bean FSWW08 did increase VEGF gene expression in CTC of prostate and in ovarian cancer patients (Table 1, Figure 24). Precursor of VEGF have not been identified in yeasts, but in almost all species, where larger tissue is formed (Table 2) [80].

The concept and limitation of "anti-VEGF" therapy in anticancer treatment is currently strongly debated among researchers, as it failed in breast cancer and there may be even an acquired resistance to antiVEGF therapy in glioblastoma, which may even increase the invasiveness of Glioblastoma [59]. VEGF 
is a marker for cellular stress in humans: If oxygen consumption is low, then VEGF is increased in pregnancy to promote blood vessel growth and oxygen supply of the fetus [61-64]. VEGF helps to reduce cellular stress. As can be seen in Figure $\mathbf{2 0}$ where reduced angiogenesis marker and DNA activity have been identified in breast cancer tissue after consumption of the fermented soy bean formulation FSWW08. The recued angiogenesis and improved barrier functions preventing the diffusion of cytokines into the general blood stream (Figure 21), which are normally responsible for depression, inflammation, fatigue and most of all for cachexia, the appetite loss (Figure 22), were also improved (Figure 22).

Both substances, Doxorubicin and fermented soy bean, had a cytotoxic effect in the human breast cancer cell line BT-474 (Table 1). Both substances increased at high doses the expression of MDR1, Doxorubicin even more. At low physiologic doses, however, fermented soy bean reduced multiple drug resistance gene MDR1 even in combination with doxorubicin.

The fact that FSWW08 led to a strong increase in the expression of the pro-apoptotic gene $\operatorname{BAX}[64,65]$ (Figure 7) in cancer, in vitro, while the traditional chemotherapeutic agent Doxorubicin left the expression of this gene unaltered shows that it might at least be beneficial to combine FSWW08 with Doxorubicin for a more effective treatment of cancer. It is not known why FSWW08 did increase BAX in CTC extracted from blood of prostate cancer (Figure 11), but left those extracted from ovarian and breast cancer unchanged (Figures 12, 13). Programmed cell death to reduce unnecessary or unwanted cells during development or disease is similar in plants and animals $[66,67]$. Common pathways in plants and animals leading to cell death has not been proven $[68,69]$. In plants, the triggering of cell death in response to an invading pathogen results in the formation of a zone of dead cells in the vicinity of the infection site [70]. This killing of host cells is frequently associated with resistance to further pathogen multiplication and spread [71]. The tobacco mosaic virus is a model plant parasite and causes host cells death around a pathogenic intruder to prevent from further migrating into the cell. Bcl-2/BAX heterodimers gene controls death and survival of cells in yeasts and in plants [72, 73] and organizes the protection of a plant against an intruder $[74,75]$.

NF-kB (nuclear factor kappa B) family transcription factors are master regulators of immune and inflammatory processes in response to both injury and infection [76]. NF-KB exists not in plant cells. However direct precursor cascades were found in plants regulating NO production and is therefore an important factor in plant physiology [81]. It was shown by many investigators that many plants can reduce NF-KB in human tissue and cells, as was shown by fermented soy beans also [77].

No clinically relevant health claims can be made from these in vitro and in vivo studies incorporating FSWW08, since larger statistically relevant studies have to be conducted. It may be, however, suggested that more studies have to be conducted combining plant based medicine with DNA repair with those conducting DNA cytotoxic mechanism. The here tested formulation is not palatable for patients used to Western food. Also it needs to be investigated, which of the ingredients besides Isoflavones may also have caused the gene modifications described in this study.

\section{REFERENCES}

[1] Somani SM, JA Romano Jr, editors. Chemical Warfare Agents: Toxicity at Low Levels. Boca Raton, FL: CRC Press, 2001.

[2] Waring MJ. DNA Modification and Cancer. Annual Review of Biochemistry 1981; 50: 159-192. http://dx.doi.org/10.1146/annurev.bi.50.070181.001111

[3] Perez-Tomas R. Multidrug Resistance: Retrospect and Prospects in Anti-Cancer Drug Treatment. Current Medicinal Chemistry 2006; 13: 1859-1876.

http://dx.doi.org/10.2174/092986706777585077

[4] Molnár J, Engi H, Hohmann J, Molnár P, Deli J, Wesolowska $\mathrm{O}$, Michalak K, Wang Q. Reversal of multidrug resistance by natural substances from plants. Curr Top Med Chem 2010; 10: $1757-68$.

http://dx.doi.org/10.2174/156802610792928103

[5] Wicha M. Cancer Stem Cells: An Old Idea-A Paradigm Shift. Cancer Res 2006; 66: 1883. http://dx.doi.org/10.1158/0008-5472.CAN-05-3153

[6] Visvader JE, Lindeman GJ. Cancer Stem Cells: Current Status and Evolving Complexities. Cell Stem Cell 2012; 10: 717-728.

http://dx.doi.org/10.1016/j.stem.2012.05.007

[7] Sethi S, Li Y, Sarkar FH. Regulating miRNA by natural agents as a new strategy for cancer treatment. Curr Drug Targets 2013; 14: 1167-74. http://dx.doi.org/10.2174/13894501113149990189

[8] Markstein M, Dettorre S, Cho J, Neumüller RA, Craig-Müller $\mathrm{S}$, Perrimon N. Systematic screen of chemotherapeutics in Drosophila stem cell tumors. PNAS 2014; 14: 4530-5. http://dx.doi.org/10.1073/pnas.1401160111

[9] Singer E, Judkins J, Salomonis N, Matlaf L, Soteropoulos P, McAllister S, Soroceanu L. Reactive oxygen speciesmediated therapeutic response and resistance in glioblastoma. Cell Death and Disease 2015; 6. http://dx.doi.org/10.1038/cddis.2014.566

[10] Macheret M, Halazonetis TD. DNA replication stress as a hallmark of cancer. Annu Rev Pathol 2015; 10: 425-48. http://dx.doi.org/10.1146/annurev-pathol-012414-040424

[11] (a) Biddlestone J, Bandarra D, Rocha S. The role of hypoxia in inflammatory disease (Review). Int J Mol Med 2015. doi: 10.3892/ijmm.2015.2079 (b) Giorgi C, Bonora M, Sorrentino 
G, Missiroli S, Poletti F, Suski JM, Galindo Ramirez F, Rizzuto R, Di Virgilio F, Zito E, Pandolfi PP, Wieckowski MR, Mammano F, Del Sal G, Pinton P. p53 at the endoplasmic reticulum regulates apoptosis in a $\mathrm{Ca2+-dependent} \mathrm{manner.}$ Proc Natl Acad Sci USA 2015. pii: 201410723.

[12] von Stechow L, Typas D, Carreras Puigvert J, Oort L, Siddappa $R$, Pines A, Vrieling $H$, van de Water $B$, Mullenders $\mathrm{LH}$, Danen EH. The E3 ubiquitin ligase ARIH1 protects against genotoxic stress by initiating a 4EHP-mediated mRNA translation arrest. Mol Cell Biol 2015. pii: MCB.0115214.

[13] Richardson C, Yan S, Vestal CG. Oxidative Stress, Bone Marrow Failure, and Genome Instability in Hematopoietic Stem Cells. Int J Mol Sci 2015; 16(2): 2366-2385. Review.

[14] Paul S, Amundson SA. Differential Effect of Active Smoking on Gene Expression in Male and Female Smokers. J Carcinog Mutagen 2014; 5: pii 1000198.

[15] Wong EY, Wong SC, Chan CM, Lam EK, Ho LY, Lau CP, Au TC, Chan AK, Tsang CM, Tsao SW, Lui VW, Chan AT. TP53-induced glycolysis and apoptosis regulator promotes proliferation and invasiveness of nasopharyngeal carcinoma cells. Oncol Lett 2015; 9(2): 569-574.

[16] Gu Y, Li P, Peng F, Zhang M, Zhang Y, Liang H, Zhao W, Qi L, Wang H, Wang C, Guo Z. Autophagy-related prognostic signature for breast cancer. Mol Carcinog 2015. http://dx.doi.org/10.1002/mc.22278

[17] Rapisarda V, Loreto C, Ledda C, Musumeci G, Bracci M, Santarelli L, Renis M, Ferrante M, Cardile V. Cytotoxicity, oxidative stress and genotoxicity induced by glass fibers on human alveolar epithelial cell line A549. Toxicol In Vitro 2015. pii: S0887-2333(14)00250-1. http://dx.doi.org/10.1016/j.tiv.2014.12.010

[18] Vaubourgeix J, Lin G, Dhar N, Chenouard N, Jiang X, Botella H, Lupoli T, Mariani O, Yang G, Ouerfelli O, Unser M, Schnappinger D, McKinney J, Nathan C. Stressed Mycobacteria Use the Chaperone ClpB to Sequester Irreversibly Oxidized Proteins Asymmetrically Within and Between Cells.Cell Host Microbe 2015. pii: S19313128(14)00462-4.

http://dx.doi.org/10.1016/j.chom.2014.12.008

[19] Ganai AA, Khan AA, Malik ZA, Farooqi H. Genistein modulates the expression of NF-KB and MAPK (p-38 and

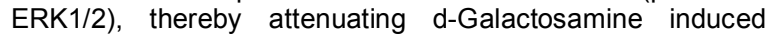
fulminant hepatic failure in Wistar rats. Toxicol Appl Pharmacol 2015. pii: S0041-008X(15)00022-8. http://dx.doi.org/10.1016/j.taap.2015.01.012

[20] Fulda S, Kögel D. Cell death by autophagy: emerging molecular mechanisms and implications for cancer therapy. Oncogene 2015. http://dx.doi.org/10.1038/onc.2014.45

[21] Shaukat Z, Liu D, Hussain R, Khan M, Gregory SL. The Role of JNK Signalling in Responses to Oxidative DNA Damage. Curr Drug Targets 2015. [Epub ahead of print].

[22] Li Y, Wicha MS, Schwartz SJ, Sun D. Implications of cancer stem cell theory for cancer chemoprevention by natural dietary compounds. J Nutr Biochem 2011; 9: 799-806.

[23] Fehm T, Hoffmann O, Aktas B, Becker S, Solomayer EF, Wallwiener D, Kimmig R, Kasimir-Bauer S. Detection and characterization of circulating tumor cells in blood of primary breast cancer patients by RT-PCR and comparison to status of bone marrow disseminated cells. Breast Cancer Research 2009; 11: R59.

http://dx.doi.org/10.1186/bcr2349

[24] Rohr UD, Gocan AG, Bachg D, Schindler AE. The effect of fermented soy (FSWW08) on blood hematology and cachexia in cancer patients. Horm Mol Biol Clin Invest 2010; 3: 391-409.

[25] Atkinson NJ, Urwin PE. The interaction of plant biotic and abiotic stresses: from genes to the field. Journal of Experimental Botany 2012; 17: 1-21. http://dx.doi.org/10.1093/jxb/ers100
[26] West CE, Waterworth WM, Sunderland PA, Bray CM. Arabidopsis DNA double-strand break repair pathways. Biochem Soc Trans 2004; 32: 964-966. http://dx.doi.org/10.1042/BST0320964

[27] Kozak J, West CE, White C, da Costa-Nunes JA, Angelis KJ. Rapid repair of DNA double strand breaks in Arabidopsis thaliana is dependent on proteins involved in chromosome structure maintenance. DNA Repair (Amst) 2014; 8: 413-419. http://dx.doi.org/10.1016/j.dnarep.2008.11.012

[28] Roy S, Roy CS, Singh SK, Das KP. AtPol A a homolog of mammalian DNA polymerase $\lambda$ in Arabidopsis thaliana, is involved in there pair of UV-B induced DNA damage through the dark repair pathway. Plant Cell Physiol 2011; 52: 448467. http://dx.doi.org/10.1093/pcp/pcr002

[29] Roy S. Maintenance of genome stability in plants: repairing DNA doublw strand breaks and chromatin structure stability. Frontiers in Plant Science 2014.

http://dx.doi.org/10.3389/fpls.2014.00487

[30] Rodriguez MCS, Petersen M, Mundy J. Mitogen-activated protein kinase signaling in plants. Annual Review of Plant Biology 2010; 61: 621-649. http://dx.doi.org/10.1146/annurev-arplant-042809-112252

[31] Zhang T, Liu Y, Yang T, Zhang L, Xu S, Xue L, An L. Diverse signals converge at MAPK cascades in plant. Plant Physiology and Biochemistry 2006; 44: 274-283. http://dx.doi.org/10.1016/j.plaphy.2006.06.004

[32] Yoshiyama KO, Sakaguchi K, Kimura S. DNA damage response in plants: conserved and variable response compared to animals. Biology (Basel) 2014; 2: 1338-1356. http://dx.doi.org/10.3390/biology2041338

[33] Biros E1, Kohút A, Biros I, Kalina I, Bogyiová E, Stubna J. A link between the p53 germ line polymorphisms and white blood cells apoptosis in lung cancer patients. Lung Cancer 2002; 35: 231-5.

http://dx.doi.org/10.1016/S0169-5002(01)00446-9

[34] Schönrock N, Exner V, Probst A, Gruissem W, Hennig L. Functional genomic analysis of CAF-1 mutants in Arabidopsis thaliana. J Biol Chem 2006; 281: 9560-9568. http://dx.doi.org/10.1074/jbc.M513426200

[35] Ramirez-Parra E, Gutierrez C. E2F regulates FASCIATA1, a chromatin assembly gene whose loss switches on the endocycle and activates gene expression by changing the epigenetic status. Plant Physiol 2007; 144: 105-120. http://dx.doi.org/10.1104/pp.106.094979

[36] Kulcheski FR, de Oliveira LFV, Molina LG, et al. Identification of novel soybean microRNAs involved in abiotic and biotic stresses. BMC Genomics 2011; 12: 307. http://dx.doi.org/10.1186/1471-2164-12-307

[37] Rotino GL, Rossoni M, Spinardi A, Bracale M. 2007. Evaluation of transgenic tomato plants ectopically expressing the rice Osmyb4 gene. Plant Science 2011; 173: 231-239.

[38] Hu WS, Lin YM, Ho TJ, Chen RJ, Li YH, Tsai FJ, Tsai CH, Day $\mathrm{CH}$, Chen TS, Huang $\mathrm{CY}$. Genistein suppresses the isoproterenol-treated $\mathrm{H} 9 \mathrm{c} 2$ cardiomyoblast cell apoptosis associated with P-38, Erk1/2, JNK, and NFKB signaling protein activation. Am J Chin Med 2013; 41: 1125-36. http://dx.doi.org/10.1142/S0192415X13500766

[39] Rohr UD, WW Li, H Ziqiang, Wainright, AE Schindler. The effect of fermented soy (FSWW08) on blood hematology and cachexia in cancer patients. Hormone Molecular Biology and Clinical Investigation 2012; 12: 407-418. http://dx.doi.org/10.1515/hmbci-2012-0028

[40] Gocan AG. D Bachg, AE Schindler, UD Rohr. Managing immunity in resistant cancer patients correlates to survival: results and discussion of a pilot study. Horm Mol Biol Clin Invest 2011; 8: 455-469.

[41] Rostagno P, Moll JL, Bisconte JC, Caldani C. Detection of rare circulating breast cancer cells by filtration cytometry and identification by DNA content: sensitivity in an experimental model. Anticancer Res 1997; 17: 2481-5. 
[42] Hardingham JE, Kotasek D, Farmer B, Butler RN, Mi JX, Sage RE, Dobrovic A. Immunobead-PCR: a technique for the detection of circulating tumor cells using immunomagnetic beads and the polymerase chain reaction. Cancer Res 1993; 53: 3455-8.

[43] Ferreira E, Cronjé MJ. Selection of suitable reference genes for quantitative real-time PCR in apoptosis-induced MCF-7 breast cancer cells. Mol Biotechnol 2012; 50: 121-126. http://dx.doi.org/10.1007/s12033-011-9425-3

[44] Klein A, He X, Roche M, Mallett A, Duska L, Supko JG, Seiden MV. Prolonged stabilization of platinum-resistant ovarian cancer in a single patient consuming a fermented soy therapy. Gynecol Oncol 2006; 100: 205-9. http://dx.doi.org/10.1016/j.ygyno.2005.08.006

[45] Alwan A, MacLean DR, Riley LM. Monitoring and surveillance of chronic non-communicable diseases: progress and capacity in high-burden countries. The Lancet 2010; 376: 1861-1868.

http://dx.doi.org/10.1016/S0140-6736(10)61853-3

[46] Luo J, Solimini NL, Elledge SJ. Principles of cancer therapy: Oncogene and non-oncogene addiction. Cell 2009; 136(5): 823-837.

http://dx.doi.org/10.1016/j.cell.2009.02.024

[47] Aggarwal BB, Danda D, Gupta S, Gehlot P. Models for prevention and treatment of cancer: Problems vs promises. Biochem Pharmacol 2009; 78: 1083-1094. http://dx.doi.org/10.1016/j.bcp.2009.05.027

[48] Noolvi MN. Natural sources as potential anti-cancer agents: A review. International Journal of Phytomedicine 2011; 3: 0926.

[49] Gocan AG, Bachg D, Schindler AE, Rohr UD. Balancing steroidal hormone cascade in treatment-resistant veteran soldiers with PTSD using a fermented soy product (FSWW08): a pilot study. Horm Mol Biol Clin Invest 2012; 10: 301-314.

[50] Bachen, EA, Manuck SB, Cohen S, Muldoon MF, Raible R, Herbert TB, Rabin BS. Adrenergic Blockade Ameliorates Cellular Immune Responses to Mental Stress in Humans. Psychosomatic Medicine 1995; 57: 366-372. http://dx.doi.org/10.1097/00006842-199507000-00008

[51] Zhang Z, Wang CZ, Du GJ, Qi Calway LW. Genistein induces G2/M cell cycle arrest and apoptosis via ATM/p53dependent pathway in human colon cancer cells. Int $\mathrm{J}$ Oncol 2013; 43: 289-96.

[52] Bao X, Fen Y, Mian Z, Xue Y, Zhi Z. Effect of genistein on the TLR and MAPK transduction cascades in lipopolysaccharide-stimulated macrophages.

[53] Sandner A, Illert J, Koitzsch S, Unverzagt S, Schön I. Reflux induces DNA strand breaks and expression changes of MMP1+9+14 in a human miniorgan culture model. Exp Cell Res 2013; 319: 2905-15. http://dx.doi.org/10.1016/j.yexcr.2013.09.004

[54] Magee PJ, Allsopp P, Samaletdin A, Rowland IR. Daidzein, $\mathrm{R}-(+)$ equol and S-(-)equol inhibit the invasion of MDA-MB231 breast cancer cells potentially via the down-regulation of matrix metalloproteinase-2. Eur J Nutr 2014; 53: 345-50. http://dx.doi.org/10.1007/s00394-013-0520-Z

[55] Zheng W, Zhang Y, Ma D, Shi Y, Liu C, Wang P. ( \pm )Equol inhibits invasion in prostate cancer DU145 cells possibly via down-regulation of matrix metalloproteinase-9, matrix metalloproteinase-2 and urokinase-type plasminogen activaton by antioxidant activity. J Clin Biochem Nutr 2012; 51: 61-7.

http://dx.doi.org/10.3164/jcbn.11-54

[56] Abbas T, Dutta A. p21 in cancer: intricate networks and multiple activities. Nat Rev Cancer 2009; 9: 400-414. http://dx.doi.org/10.1038/nrc2657

[57] Levine AJ. The P53 tumor suppressor gene. Nature 1991; 351: 453.

http://dx.doi.org/10.1038/351453a0
[58] Tanner M, Jarvinen P, Isola J. Amplification of HER-2/neu and topoisomerase llalpha in primary and metastatic breast cancer. Cancer Res 2001; 61: 5345-8.

[59] Piao Y, Liang J, Holmes L, Henry V, Sulman E, de Groot JF. Acquired resistance to anti-VEGF therapy in glioblastoma is associated with a mesenchymal transition. Clin Cancer Res 2013; 19: 4392-403.

http://dx.doi.org/10.1158/1078-0432.CCR-12-1557

[60] Zhao D, Pan C, Sun J, Gilbert C, Drews-Elger K, Azzam DJ, Picon-Ruiz M, Kim M, Ullmer W, El-Ashry D, Creighton CJ, Slingerland JM. VEGF drives cancer-initiating stem cells through VEGFR-2/Stat3 signaling to upregulate Myc and Sox2. Oncogene 2014. http://dx.doi.org/10.1038/onc.2014.257

[61] Chedraui P, Solis EJ, Bocci G, Gopal S, Russo E, Escobar GS, Hidalgo L, Pérez-López FR, Genazzani AR, Mannella P, Simoncini T. Feto-placental nitric oxide, asymmetric dimethylarginine and vascular endothelial growth factor (VEGF) levels and VEGF gene polymorphisms in severe preeclampsia. J Matern Fetal Neonatal Med 2013; 26: 22632.

http://dx.doi.org/10.3109/14767058.2012.733760

[62] Goel HL, Mercurio AM. VEGF targets the tumour cell. Nature Reviews Cancer 2013; 13: 871-882. http://dx.doi.org/10.1038/nrc3627

[63] Keunen O, Johansson M, Oudin A, Sanzey M, Rahim SA, Fack F, Thorsen F, Taxt T, Bartos M, Jirik R, Miletic H, Wang J, Stieber D, Stuhr L, Moen I, Rygh CB, Bjerkvig R, Niclou SPAnti-VEGF treatment reduces blood supply and increases tumor cell invasion in glioblastoma. Proc Natl Acad Sci 2011; 108: 3749-5.

http://dx.doi.org/10.1073/pnas.1014480108

[64] Krajewski S. et al. Prognostic significance of apoptosis regulators in breast cancer. Endocr Relat Cancer 1999; 6: 29-40. http://dx.doi.org/10.1677/erc.0.0060029

[65] Ikeguchi MS. et al. Quantitative analysis of expression levels of $\mathrm{BAX}, \mathrm{Bcl} 2$ and survivin in cancer cells during cisplatin treatment. Oncol Rep 2002; 9: 1121-6. http://dx.doi.org/10.3892/or.9.5.1121

[66] Pennell RI, Lamb C. Plant Cell 1997; 9: 1157-1168. http://dx.doi.org/10.1105/tpc.9.7.1157

[67] Greenberg, JT. Plant Mol Biol 1997; 48: 525-545.

[68] Heath MC, Eur. J Plant Pathol 1998; 104: 117-124. http://dx.doi.org/10.1023/A:1008645520976

[69] Gilchrist DG. Annu. Rev. Phytopathol 1998; 36: 393-414. http://dx.doi.org/10.1146/annurev.phyto.36.1.393

[70] Lacomme C, Santa Cruz S. Bax-induced cell death in tobacco is similar to the hypersensitive response. Proc Natl Acad Sci 1999; 96: 7956-7961.

http://dx.doi.org/10.1073/pnas.96.14.7956

[71] Goodman RN, Novacky AJ. The Hypersensitive Reaction in Plants to Pathogens. A Resistance Phenomenon 1994 APS Press, St. Paul, MN.

[72] Kromer G. Nat Med 1997; 3: 614-620. http://dx.doi.org/10.1038/nm0697-614

[73] Oltvai ZN, Milliman CL, Korsmeyer SJ. Cell 1993; 74: 609619. http://dx.doi.org/10.1016/0092-8674(93)90509-O

[74] Zha H, Aime-Sempe C, Sato T, Reed JC. J Biol Chem 1997; 271: $7440-7444$.

[75] Simonen M, Keller H, Heim J. Eur J Biochem 1997; 249: 8591. http://dx.doi.org/10.1111/j.1432-1033.1997.t01-1-00085.x

[76] Napetschnig J, Wu H. Molecular Basis of NF-KB Signaling Biophysics 2013; 42: 443-468. http://dx.doi.org/10.1146/annurev-biophys-083012-130338

[77] Golan-Goldhirsh A, Gopas J. Plant derived inhibitors of NFKB. Phytochemistry Reviews 2014; 13: 107-121. http://dx.doi.org/10.1007/s11101-013-9293-5 
[78] Rouleau M, Marsolais F, Richard M, Nicolle L, Voigt B, Adam $G$ Varin L. Inactivation of Brassinosteroid Biological Activity by a Salicylate-inducible Steroid Sulfotransferase from Brassica napus. The Journal of Biological Chemistry 1999; 274: 20925-20930.

http://dx.doi.org/10.1074/jbc.274.30.20925

[79] Thornton. Evolution of vertebrate steroid receptors from an ancestral estrogen receptor by ligand exploitation and serial genome expansions. PNAS 2001; 98: 5673-79.

[80] Holmes DHI, Zachar I. The vascular endothelial growth factor (VEGF) family: angiogenic factors in health and disease.

Genome Biology 2005; 6: 209.

http://dx.doi.org/10.1186/gb-2005-6-2-209
[81] Negi S, Kharshiing EV, Sharma R. NO way! Is nitric oxide level in tomato regulated by a mammalian IKK/NFKB-like signaling pathway? Plant Signal Behav 2011; 6(7): 10491052.

http://dx.doi.org/10.4161/psb.6.7.15633

[82] Goslin K, Schindler AE, Rohr UD. Prolonged Stabilization of Amyotrophic Lateral Sclerosis (ALS) with a specially fermented Soy Product (FSWW08): Case Report and Discussion. Journal of Nutritional Therapeutics 2013; 2: 1.

DOI: http://dx.doi.org/10.6000/1927-5951.2015.05.03.1

(C) 2015 Volko and Rohr; Licensee Lifescience Global.

This is an open access article licensed under the terms of the Creative Commons Attribution Non-Commercial License (http://creativecommons.org/licenses/by-nc/3.0/) which permits unrestricted, non-commercial use, distribution and reproduction in any medium, provided the work is properly cited. 